\title{
Foça Club Med Tatil Köyü: Tarihçesi, Özellikleri ve Türkiye Turizmi için Sonuçları
}

Foca Club Med: Its History, Characteristics and Consequences for the Turkish Tourism Industry

\author{
Metin KOZAK*, Yeşim COŞAR ** \\ *Prof. Dr., Dokuz Eylül Üniversitesi, Reha Midilli Foça Turizm Fakültesi, 35680, Foça, İzmir. \\ E-posta: metin.kozak@deu.edu.tr \\ **Yrd. Doç. Dr., Dokuz Eylül Üniversitesi, Fevziye Hepkon Uygulamalı Bilimler Yüksekokulu, 35460, Seferihisar, İzmir. \\ E-posta: yesim.cosar@deu.edu.tr
}

\section{MAKALE BILGILERI \\ Makale işlem bilgileri: \\ Gönderilme tarihi: 3 Mart 2016 \\ Birinci düzeltme: 9 Haziran 2016 \\ Kabul: 23 Temmuz 2016}

Anahtar sözcükler: Club Med Foça, Club Méditerranée, Kamu yatırmlar, Özel sektör, Yabancı sermaye, Zincir işletmeler, Turizmin etkileri.

\section{ARTICLE INFO}

Article history:

Submitted: 3 March 2016

Resubmitted: 9 June 2016

Accepted: 23 July 2016

Key words: Club Med Foca, Club Méditerranée, Public sector, Private sector, Foreign capital, Chain hotels, Impacts of tourism.

\section{Öz}

1950'li yıllardan itibaren Akdeniz ülkelerinde turizm gelişmeye başlar. 1960'lı yıllardan itibaren T.C. Emekli Sandığı ve TC. Turizm Bankası turizm sektörünü geliştirme yönünde hem "yatırımcı" hem "işletmeci" olarak önemli görevler üstlenir. Foça Fransız Tatil Köyü de (Club Méditerranée), yerli yatırımcı ile yabancı işletmeciliğin bir örneğini oluşturur. Bu tesis, Türkiye'de şehir otel işletmeleri dışında orta ya da büyük ölçekli turizm tesislerinin bulunmadığı kıyı bölgelerinde ilk tatil köyü projesiyle ortaya çıkar. Bu çalışma kapsamında da, Club Med Foça Tatil Köyü'nün yatırım süreci, işletmeye açılışı, turizm sektörü açısından tașıdığı özellikler, Foça'nın ekonomik, toplumsal ve fiziksel yapısı üzerindeki etkileri ayrıntılı bir șekilde ele alınmaktadır. Çalıșmanın tamamlanmasında basında yer alan haberler, Bakanlık bürokratlarının görüşleri, belirli dönemlerde yerel yönetimlerde ve tesiste görev alanlar ile tesisten yararlanan misafirlerin birebir gözlem ve deneyimlerinden yararlanıldı. Tesisin yerel anlamda Foça ve genel anlamda da Türkiye turizm sektörü için önemli etkilere sahip olduğu görülmektedir.

\begin{abstract}
The international tourism industry has begun recording remarkable progress in the Mediterranean countries since the 1950s. Commencing from the 1960s, Emekli Sandığı (Pension Fund) and Turizm Bankası (Tourism Bank), both as investors and entrepreneurs, have taken the responsibility of developing the national tourism industry in Turkey. Club Med Foca (Club Méditerranée) became an example of the cooperation between domestic investors and foreign entrepreneurs. This business emerged as the first case of holiday villages operating on coastal zones where there were no medium or large-scale hospitality businesses in that period of Turkey, except metropolitan cities. This study aims to investigate the investment periods of Club Med Foca and its opening into the business, characteristics from the tourism industry perspective, and major impacts on the economic, social and physical structure of Foca, as a small fishery town. In completing the study, data were collected through news on local media, opinions of bureaucrats affiliated with the Ministry of Tourism, employees worked and guests stayed at Club Med Foca. The conclusions provide the summary that Club Med Foca has had significant consequences both at local and national levels.
\end{abstract}

\section{Giriş}

Son bir yüzyıllık dönem, dünyanın ekonomik ve toplumsal yapısında oldukça ciddi değişimleri hızlı bir şekilde oluşturan ve belirli aralıklarla değişimi ve dönüşümü de gerçekleştiren bir kesit olarak ele alınmaktadır. Kapitalizm sonucunda küreselleşme olgusu kendisini göstererek uluslararası ekonomideki sınırlar kaldırılır, kitlesel üretim ve buna bağlı olarak kitlesel tüketim de kendini gösterir. Üretim araçlarının özelleştirilmesi gibi neo-liberal ekonomi politikaları dün- yanın siyasi haritasını değiştirir, bu kapsamda da özel sektörün teşvik edilmesi bir devlet politikası halini alır (Fletcher 2011). Post-Fordizm uygulamaları sonucunda, mekanik ve dijital teknolojide önemli bir gelişme gözlenir, firmalar ve hatta ülkeler belirli ürün gruplarının sunumunda uzmanlaşarak özellikli bir hale gelir. Bu gelişme ise, ürün çeşitliliğine yol açarak talep tarafında ürün farklılaştırması ve pazar bölümlendirmesi bağlamında kitlesel ya da lüks tüketim gibi farklı kavramların da kendini göstermesine neden olur. Kapitalizm bağlamında neo-liberal ve post- 
Fordist üretim politikalarının en yoğun hissedildiği dönem, hiç kuşkusuz, Asya ülkelerinin de dünya ekonomisinde söz sahibi olmaya başlamaları ile birlikte rekabetin sertleştiği ve turizm sektöründe ütopyalaşmanın yoğunlaştığ 21 . yüzyılın başlangıcıdır (Simpson 2016).

Bu kapsamda, özellikle İkinci Dünya Savaşı sonrasında bir yandan arz tarafından görülen yeniden sanayileşme çabaları diğer yandan havayolu taşımacılığındaki hızlı ilerlemeler diğer yandan ücretli tatiller ve eğitim düzeyinin artması gibi talep tarafından görülen gelişmeler, 1950'li yıllardan başlayarak turizm sektörünün de önemsenmesine yol açar (MacCannell 1999; Honey 2008; Fletcher 2011). Gelişmiş Kuzey Avrupa ülkeleri, vatandaşlarına ve çalışanlarına tatil olanakları yaratabilmek için de Akdeniz ülkelerini tatil merkezi olarak hedefledikleri görülür. Kamunun turizm sektöründeki payı sadece yatırım olarak yer almaz, aksine halkın ve çalışanların da tatil gereksinimlerinin karşılanması için teşvik edilmeleri zorunluğu kendisini gösterir. Bu tür uygulamaların sıklıkla görülmeye başlandığı 1960'lı yıllarda, Türkiye'de de turizm sektörünün gelişmesinde iki kamu kurumunun önemli görevler üstlenmesine tanık olunur: T.C. Emekli Sandığı ve T.C. Turizm Bankası. Birincisi, daha çok sahip olduğu mülkleri yerli ya da yabancı firmalara kiraya vererek "yatırımcı" olarak dikkat çekerken; ikincisi ise, hem yatırımcı hem de işletmeci olarak önemli katkıda bulunur. T.C. Turizm Bankası'na ait tesislerin büyük bir bölümü özelleştirilir, banka kapatılarak varlıkları devredilir. Ancak T.C. Emekli Sandı̆̆g'nın sahip olduğu varlıklar hala aktif olup, faaliyetlerine devam etmektedir.

Üretimde özel sektör girişimini savunan neoliberal politikaların Türkiye'de uygulanması 1950'li yıllarda başlamakla birlikte, 1960'lı yıllarda artarak devam eder ama asıl ivme kazand1ğ1 dönem 1980'li yıllar olarak tarihe geçer. Foça Fransız Tatil Köyü de (Club Méditerranée), yerli yatırımc ile yabancı işletmeciliğin bir örneği olarak kendisini gösterir. Bu tesis, Türkiye'de şehir otel işletmeleri dışında orta ya da büyük ölçekli turizm tesislerinin bulunmadığ 1 kıyı bölgelerimizde, belki de bir başlangıç amacıyla, ilk tatil köyü projesiyle ortaya çıar. 1960'1 yıllar, turizm sektöründe özellikle yatırım konusunda profesyonelleşme çabalarının başladığı bir döneme işaret eder. 1963 yılında T.C. Turizm ve Tanıtma Bakanlığı kurulur, planlı döneme geçilerek turizm sektörüne de yer verilmeye başlanır. Daha çok kültür ve doğa turlarını talep eden "maceracı" ya da "keşfedici" turist tiplerinin egemen olduğu bu dönemde, tesislerin niteliği de daha çok temel gereksinimlerin giderilmesine dönüktür.

T.C. Turizm ve Tanıtma Bakanlığı'nın kurulması ile birlikte, Türkiye'de turizm sektörünün Devlet eliyle geliştirilmesi konusunda da bazı politikalar belirlenerek çalışmalara başlanır. Beş yıllık kalkınma planlarında da yer almaya başlayan turizm sektörünün geliştirilmesi politikasının yaşama geçirilmesi için kıyı bölgelerdeki küçük tesislerin yanı sıra, ortak ve büyük ölçekli tesislerin de inşa edilmesine öncelik verilir. Böylelikle zengin Avrupalı turistlerin Türkiye'ye çekilmesi hedeflenir. Bu kapsamda, bir Fransız şirketi olan Club Med, Foça, Kemer ve Kuşadası gibi önemli turizm yörelerinde tatil köyü açma kararı alır. Bu çalışma kapsamında da, Club Med Foça Tatil Köyü'nün yatırım süreci, işletmeye açılışı, Türkiye turizm sektörü açısından taşıdığı özellikler, Foça'nın ekonomik, toplumsal ve fiziksel yapısı üzerindeki etkileri ayrıntılı bir şekilde ele alınmaktadır. Çalışmanın tamamlanmasında basında yer alan haberler, Bakanlık bürokratlarının yapmış olduğu açıklamalar, belirli dönemlerde yerel yönetimlerde ve tesiste görev alanlar ile tesisten yararlanan misafirlerin birebir gözlem ve deneyimlerinden yararlanılmaktadır.

\section{KAMU YATIRIMLARI VE TURIZM}

Burkart ve Medlik, 1974 yılında yazdıkları şaheser kitaplarında, iki dünya savaşı arasındaki dönemde Devletlerin turizm sektörüne önem vermeye başladıklarını dile getirir. Bunun gerekçesi ise, yoksullaşan ülke ekonomilerinin canland1rılması ve ödemeler dengesi gibi konular nedeniyle, hizmetler sektörü içinde turizmin ortaya çıkaracağı ekonomik etkilere vurgu yapılmasıdır. İkinci Dünya Savaşı'nın izleyen dönemlerde ise, turizm sektörüne verilen önem daha da artar. Birçok Avrupa ülkesi, Kuzey Amerika pa- 
zarını çekebilmek için tanıtım faaliyetlerine başlar. Örneğin; İngiltere, Britanya Seyahat ve Tatil Derneği'ni (günümüzdeki adı Britanya Turizm Ofisi) kurar; sonrasında da Turizmin Geliştirilmesi Yasası'nı çıarırı (1969). Bu yasa ile bir yandan yurtdışı tanıtımlarına ağırlık verilirken; diğer yandan da mevcut tesislerin yenilenmesi ve yenilerinin yapılması konusunda da kredi ve teşvik düzenlemesi yapılır.

Dünyadaki benzer gelişmelere paralel olarak, Türkiye'de turizm sektörü deyince, ilk akla gelen yine kamu yatırımlarının öncülüğü olur. İkinci Dünya Savaşı sonrasında dünyada özel bir ilgi görmeye başlayan turizm yatırımları ve bunun sonucunda üniversiteler düzeyinde kendisini gösteren eğitim ve araştırma konusu gelir. Gerek yüksek maliyet gerekse talebin belirsizliği nedeniyle o dönem, yapılan yatırımın geri dönmesi uzun yılları gerektirir Bu kapsamda T.C. Emekli Sandığı, T.C. Turizm Bankası ve Vakıflar Bankası gibi kamu kurum ve kuruluşları turizmde yatırımlara başlar, tamamladıkları tesisleri de ulusal ya da uluslararası zincirlere kiraya verirler. 1955 yılında hizmete açılan İstanbul Hilton, sonrasında İstanbul Tarabya Oteli, İstanbul Maçka Oteli, İzmir Büyük Efes Oteli, Club Med Foça ve Kuşadası, T.C. Emekli Sandığı'na ait şehir otelleridir. Sapanca Vakıflar Oteli, Vakıflar Bankası'na aittir. İzmir Çeşme Büyük Oteli de, T.C. Turizm Bankası tarafından tamamlanır. Ulusal turizm sektörü için öncü rolü üstlenen ve eğitim anlamında birçok yöneticinin yetişmesine aracıllk eden bu tesislerin birçoğunun mülkiyet ya da işletme hakkının, kamunun yatırımlardan çekilmesi ile birlikte, günümüzde özel sektöre devredildiği de bilinmektedir. MOKAMP, TUSAN ve TURBAN gibi zincir tesislerin de dönemin turizm sektörünün gelişiminde etkili olduğunu belirtmekte yarar görülmektedir.

\section{ZINCIR KONAKLAMA TESISLERI: MISYONU VE GELişiMi}

Uluslararası ölçekte konaklama tesislerinin ilk ortaya çıkışı, E.M. Statler'in öncülüğü ile Amerika Birleşik Devletleri olur (1908). Sonraki dönemlerde, Conrad Hilton (Hilton Worldwide), Ernest Henderson ve Robert Moore (Sheraton), faaliyetlerini uluslararası ölçeğe taşıyan ve grup otel konseptinin gelişmesini sağlayan zincir işletmelerdir (Gee 2008). Finans riski azaltmak amacıyla, 1960'lı yıllarda zincir otel işletmeleri, daha çok gelişmiş ülkelerin büyük şehirlerinde kurulmaya başlanır. Kitle turizminin ve havayolları ulaşımının gelişmesi ile birlikte, gelişmekte olan ülkelerde de zincir işletmelerin kurulduğu görülür (Gee 2008). Bu kapsamda, Türkiye'de ilk tesisini açan işletme ise İstanbul Hilton olur (1955). Bunu Club Med izler (1966). Tablo 1 üzerinde de görüleceği üzere, 1980'li yıllarla birlikte, kıyı ve şehir otelciliğinde faaliyet göstermek amacıyla, yatırım yapan uluslararası zincir sayısı ciddi artış gösterir (Resort Dergisi 2015).

İkinci Dünya Savaşı sonrasında dünyada turizm sektörünün gelişmeye başlaması ile birlikte, özellikle Amerika Birleşik Devletleri konaklama sektöründen yüksek kar elde etmeye başlar. Bu durum, dünyada zincir otel işletmelerinin kurulmasına yol açar (Kozak, Kozak ve Kozak 2015). Avrupa'da ise, o yıllarda işçilik maliyetleri yüksektir (Burkart ve Medlik 1974). Zincir işletmelerin kurulması, dünyada turizm sektörünün gelişmesinde önemli katkısı olur (Burkart ve Medlik 1974). Çalışma biçimi, imtiyaz hakkı, yönetim sözleşmesi, ortak girişimler, stratejik ortaklıklar ya da kiralama şeklinde olabilir (de Wit ve Meyer 1998). Günümüzün keskinleşen rekabet ortamında zincir işletmelerin bazı üstün yanlarına vurgu yapılmaktadır. Bunlardan bazıları, güçlü markanın yaratılması, pazar payının arttırılması, riskin dağıtılması, ölçek ekonomisi oluşturarak satınalma maliyetinin azaltılması, pazarın çeşitlendirilmesi, yönetim ve teknik maliyetlerin düşürülmesi, uygulamalar ve teknolojik yatırımlar konusunda güncelerin takip edilmesi gibi (Lim ve Wentling 1988; Johnson ve Vanetti 2005; Jones ve Hill 2013). Hilton, Club Med gibi zincir işletmelerin farklı grup müşterileri için farklı özellikte ve isimde yeni markalar yaratarak, yeni ülkelere ya da şehirlere giriş yaparak pazar bölümlendirmesine gittikleri bilinmektedir.

\section{TURIZMIN TOPLUMSAL, EKONOMIK VE FIZIKSEL ETKILERi}

İkinci Dünya Savaşı sonrasında, bir yandan turizm yatırımlarına ağırlık vererek tatil amaçlı 
Tablo 1. Türkiye'deki Yabancı Zincir, Grup ve Markalar (Geliş tarihine göre)

\begin{tabular}{|c|c|c|c|}
\hline Zincir adı & Yılı & Zincir adı & Yılı \\
\hline Hilton & 1955 & Maritim & 2004 \\
\hline Club Med & 1966 & Calimera & 2005 \\
\hline Pullman/Mercure & 1970 & Ibis & 2007 \\
\hline İntercontinental & 1971 & Novotel (6) & 2007 \\
\hline Valtur & 1971 & Blue Collection & 2008 \\
\hline Sheraton & 1975 & Howthorn & 2008 \\
\hline Robinson Clubs & 1984 & Sensimar & 2008 \\
\hline Meridien & 1986 & W Hotels & 2008 \\
\hline Ramada & 1986 & Courtyard & 2009 \\
\hline Alba Club & 1987 & LTI & 2009 \\
\hline Aldiana & 1987 & Primasol & 2009 \\
\hline Inter & 1987 & Sentido-T. Cook & 2009 \\
\hline Best Western & 1988 & Doubletree by Hilton & 2010 \\
\hline Iberotel & 1988 & Edition & 2010 \\
\hline Marco Polo & 1988 & Hilton Garden Inn & 2010 \\
\hline Paradise & 1988 & Holiday Inn Expres & 2010 \\
\hline Steigenberger & 1988 & Club Seno-TUI & 2011 \\
\hline Grup Sol & 1989 & Hampton by Hilton & 2011 \\
\hline Corinthia & 1990 & Le Meridien & 2011 \\
\hline Holiday Inn & 1990 & Lugal Luxury & 2011 \\
\hline Kempinski & 1991 & Purovida-TUI & 2011 \\
\hline Movenpick & 1991 & St. Regis & 2011 \\
\hline Swissotel & 1991 & Viverde-TUI & 2011 \\
\hline Conrad & 1992 & Soho House & 2012 \\
\hline Global Hyatt & 1993 & Sunprime Resort-T. Cook & 2012 \\
\hline Penta & 1993 & Clairon & 2014 \\
\hline Marriott & 1994 & Jumeriah Hotels & 2014 \\
\hline Renaissance & 1994 & Mandarin Oriental & 2014 \\
\hline Four Seasons & 1996 & Raffles & 2014 \\
\hline Radisson Blu & 1998 & Shangri-La & 2014 \\
\hline Ritz Carlton & 1999 & Smartline-Thomas Cook & 2014 \\
\hline Iberostar & 2002 & \multicolumn{2}{|c|}{ SunConnect-Thomas Cook2014 } \\
\hline Crown Plaza & 2003 & Missoni & 2015 \\
\hline Barcelo & 2004 & Rezidor & 2015 \\
\hline
\end{tabular}

Kaynak: http://resortdergisi.com/dergi/155/\#p=184

kıyı turizmi canlandırılmaya çalışılırken, diğer yandan da pazarlama ve tanitım gibi faaliyetleri içeren işletmeciliğe yönelik çalışmaların yürütüldüğü görülür (Burkart ve Medlik 1974; Vukonic
2012). Yukarıda da vurgulandığı gibi, savaşın beraberinde getirdiği kaynak sorunu nedeniyle bu yıllar yönlendirme amaçlı olarak kamunun birçok ülkenin turizm yatırımlarında ağırlıklı olarak ve doğrudan kendisini hissettirdiği bir dönemi işaret eder. Ancak 1970'li yıllara gelindiğinde, turizmdeki gelişmenin ortaya çıkardığı etkiler kendisini göstermeye başlar. Bu gelişme sonucunda ise, turizm araştırmalarında yeni konuların çal1şılması zorunlu bir hal alır. Bunlar, turizmin, gidilen bölgenin ekonomik, toplumsal ve fiziksel yapısı üzerinde ortaya çıkarmış olduğu dolaylı ya da doğrudan etkileri olacaktır (Burkart ve Medlik 1974; Mill ve Morrison 1992; Wall ve Mathieson 2006).

Ekonomik açıdan bakıldığında, turizmin bir bölgede yarattığı en temel etkinin gelir ve istihdam üzerinde olduğu görülür (Burkart ve Medlik 1974; Mill ve Morrison 1992). Turistlerin gereksinimlerini doğrudan karşılayan, konaklama, yiyecek-içecek ve ulaştırma gibi işletmelerin yarattığ 1 gelir, doğrudan gelir etkisi olarak adlandırılır. Turizm amaçlı seyahat eden tüketicilere hizmet vermeyen ama bu gruplara hizmet veren işletmeler ile olan ilişkilerinden doğan gelir dolaylı gelir etkisi olarak adlandırılır. Doğrudan ve dolaylı gelir etkisi ile kazanılmış olan gelirin yeniden harcanması ile oluşan gelir ise, uyarılmış gelir etkisi adını alır.

Turizmin geliştiği bölgelerde yeme-içme gereksinimlerinin tarım ürünlerine olan talebi arttırması sonucu tarım sektörü olumlu yönde etkilenmektedir. Tarım ürünleri değerlenmekte ve tarım ile uğraşan kişilerin gelirinde artış olmaktadır. Turizm kırsal bölgelerde de istihdam yaratarak tarım kesiminde çalışanların turizm sektöründe çalışmasına olanak sağlayarak mevsimlik işsizliği de önlemektedir. Yapılan araştırmalarda, turizmin gelişme gösterdiği bölgelerde turizme bağlı olan işletmelerde görev yapan çalışanların turizmin bölgesel etkileri konusunda daha bilinçli oldukları görülmektedir (Caneday ve Zeiger 1991). Diğer yandan, özellikle kırsal bölgelerde turizmin gelişmesi ile birlikte, arazi fiyatlarında artış yaşanmaktadır. Arazi fiyatlarının artması, sahipleri için fayda sağlarken; arazi mülkiyetinin parçalanmasına ve yüksek fiyat ile el değiştirerek 
bölgesel enflasyona neden olabilmektedir (Mathieson ve Wall 1992). Son olarak, turizm sektörünün gelişmesi ile birlikte, bölgedeki altyapı ve üstyapı hizmetleri de geliştirilir ve iyileştirilir; bu durum, yerel halkın da bu tür hizmetlerden yararlanmasına olanak sağlar (Inskeep 1991).

Toplumsal etki açısından, bir bölgede turizmin gelişmesi ile birlikte kültürler arasında etkileşim oluşur (Doğan 1989; 2004). Farklı kültürü temsil eden insanların birbirlerini tanıması ile birlikte, aralarında dostluk ve arkadaşlık ilişkileri kurulur; bu durum, toplumlar arasında barış ve hoşgörünün artmasını sağlar. Turizm geliştiği bölgelerde kurulan otel işletmelerinde özellikle kat hizmetleri departmanında kadın çalışan sayısının fazla olması; kadınların da ekonomik özgürlüklerini kazanmalarını sağlayarak cinsiyet eşitliğine yol açar (Kozak, Kozak ve Kozak 2015). Turistler ile iletişim kurmak isteyen halk, yabancı dil öğrenme gayreti içerisine girmekte; yerel yönetimler ve kurumlar tarafından da dil kursları açlarak halk desteklenmektedir. Yerel halk yaşadığı bölgeyi, turizmin gelişmesi ile birlikte daha iyi tanımakta; tarihi ve kültürel değerlerine sahip çıkılması gerektiği bilincini önemsemektedir.

Ziya Eralp (1974) tarafından tamamlanan "Turizmin Toplumsal Değiş̧imine Sosyo-Ekonomik Etkisi" başlıklı eser, turizmin toplumsal etkileri konusunda Türkiye'de çalışılan ilk konulardan olup, turizm sosyolojisi alanına özgün katkı yapar. O dönemde iç turizmde gelişmeye başlamış olan Balıkesir'in Erdek ilçesi ile turizmde gelişmemiş bir yöre olarak seçilen Ankara'nın Kalecik ilçesini ele alarak turizmin toplumsal değişim üzerindeki etkisini ele alan araştırmasının sonuçlarını içerir. Bu çalışmasında Eralp, turizmin yarattığ istihdam ve gelir yaratıcı etkisi ve alışkanlıklar üzerinde meydana getirdiği değişim ile aynı zamanda o yörenin yaşam kalitesi üzerinden toplumsal yapısında da bir değişime yol açtı̆̆ını açık bir şekilde vurgular. İzleyen yıllarda yürütülen çalışmalarda da, Türkiye'de turizmin olumlu ve olumsuz toplumsal etkileri ayrıntılı olarak ele alınır (Özdemir 1992; Doğan 2004).

Turizmin bulunduğu bölge üzerinde de olumlu ve olumsuz bazı fiziksel etkileri de bulunmaktadır (Briassoulis 2000; Hall ve Lew 2009; Kozak,
Kozak ve Kozak 2015). Ülkenin ya da yerel halkın turizm sektöründen gelir elde etmeye başlamasıyla birlikte, bölgelerinde bulunan tarihi eserlerin iyileştirilmesi ya da eski kimliklerine dönüştürülmesi konusunda çaba gösterilebilir. Halk, çevresel değerlere karşı daha hassas olması gerektiği konusunda eğitilebilir. Ek olarak, son yılların moda kavramı olan, fiziksel değerlerin sürdürülebilirliği konusunda yerel, ulusal ya da uluslararası ölçekte bazı önlemlerin alınması kendini gösterebilir. Olumsuz etkileri arasında ise, gürültü ve su dahil doğanın kirliliği kendini gösterebilir. Plansız kentleşme ortaya çıkabilir. $\mathrm{Bu}$ tür gelişmelerin sonucunda halkın biyolojik ve psikolojik dengesinde bazı sağlık sorunları görülebilir.

\section{YÖNTEM}

Türkiye turizm sektörünün gelişimine öncülük eden ve yatırım yaptığı yerleşimlerin ekonomik ve sosyal bakımlardan değişimine katkıdan bulunan Club Med Tatil Köyü zincirlerinin Foça'da açmış olduğu tesisin tarihçesi, gelişimi ve yörenin ekonomik, toplumsal ve fiziksel yapısı üzerindeki etkisini ele alan bu çalışmada birebir görüşme tekniğinin yanısıra ulusal basında ve kitaplarda yer alan bazı ikincil veri kaynakları da kullanıldı. Bu kapsamda, ilk olarak, öncelikle basinda yer alan haberlerin taraması yapılarak tesisin geçmişi ya da işleyişi hakkında bilgi toplanmaya çalışıldı. İkinci aşamada, Anadolu Üniversitesi tarafından yürütülen "Türkiye Turizmi Sözlü Tarih Araştırması" başlıklı projenin bazı çıktılarından yararlanıldı. Proje kapsamında görüşülen Mukadder Sezgin, Adnan Özaktaş, Güman Kızıltan ve Haluk Akar gibi dönemin bürokratlarının Club Med Foça'nın kuruluşu aşamasında yapmış oldukları tanıklıklarına dayalı olarak verdikleri sözlü bilgiye başvuruldu. Son aşamada da, tesisin kuruluşu aşamasında yerel yönetimlerde görev alan, tesisin açılmasıyla birlikte personel olarak çalışmış ya da müşteri olarak konaklama yapmış yedi kişiyle yüz yüze (no:1-7) ve bir kişiyle de (no:8) telefon görüşmesi yapıldı (Tablo 2).

Görüşmede kartopu yöntemi kullanılarak öncelikle bir kaynak kişiye ulaşarak oradan diğerlerine ulaşılmaya çalışıldı. Görüşmeler, 11 Aralık 
Tablo 2. Görüşme yapılan kişi listesi

\begin{tabular}{ll}
\hline Katılımcı No & Görevi \\
\hline 1 & Foça Reha-Necla Midilli Vakfi çalışanı \\
\hline 3 & Club Med restoran ve bar çalışanı \\
\hline 4 & Club Med satın alma ve depolama çalışanı \\
\hline 5 & Geçmiş dönem Foça Belediyesi çalışanı \\
\hline 6 & Geçmiş dönem Foça Belediyesi çalışanı \\
\hline 8 & Fransızca Öğretmeni, Club Med tercümanı \\
\hline
\end{tabular}

2015 tarihinde saat 11.00 ile 17.00 arasında Foça şehir merkezinde gerçekleştirildi. Üç kişilik bir grupla şehir merkezindeki bir işyerinde ay$\mathrm{n} 1$ anda görüşmeler tamamlandı (Katılımcı 1, 2, 3). Diğer dört görüşme ise sırasıyla kafeteryada (Katılımcı 4), işyerinde (Katılımcı 5, 7) ve evde (Katılımcı 6) gerçekleştirildi. Karşılıklı sohbete "tesis hakkında bildiklerinizi anlatır misınız?" şeklinde genel bir soruyla başlanarak soru-yanıt şeklinde devam edildi. Görüşme yapılan kişinin emin olamadı ̆̆ 1 bazı bilgiler, görüşme sırasında yapılan telefon ya da yüz yüze görüşme ile bir başka kişiyle doğrulanmaya çalışıldı. Her kişi konuşurken yazarlardan birisi kâğıda not aldı. Görüşmelerin bitmesinden itibaren iki gün içinde de bütün notlar yazılı olarak bilgisayar ortamına aktarıldı. Sonrasında Foça Club Med tesisinin aç1lışı döneminde T.C. Turizm ve Tanıtma Bakanlığı'nda görev yapan ve görüşmelerde tercüman olan bulunan kişiyle de 15 Şubat 2016 tarihinde 40 dakikalık bir telefon görüşmesi gerçekleştirildi (Katılımcı 8). Tamamlanmış metin, Club Med Foça ile aşinalığ tılımcı 1, 4, 8) tarafından tekrar okunarak olası uyuşmazlığın giderilmesi ya da eksik kısımların tamamlanması yoluna gidildi.

\section{CLUB MED: DÜNYADAKI GELIŞiMi}

Şirketin internet sitesinde yer alan bilginin yanısıra görüşmelerden elde dilen bilgi biraraya getirildiğinde, kuruluşundan günümüze değin tarihsel gelişiminin şu şekilde anlatılması mümkündür. Club Méditerranée, su polosu şampiyonu Blitz tarafından 1950 yılında kurulur. Kısa adı Club Med şeklindedir. O dönemde İspanya'nın
Majorka Adası'nda faaliyet gösteren düşük fiyatlı çadır turizminin yapılması amaçlanır. 1953 yılında, sonraki yıllarda tesisin liderliğini üstlenecek olan Gilbert Trigano ile işbirliği yapılır. İlk Club Med tesisi, İtalya'da açılır (1954). Tesis, Baron Edmond de Rothschild tarafından satın alınır (1961); liderliği ise, 30 yıl boyunca Trigano tarafından yürütülür (1963-1993). 1963 yılından başlayarak çeşitliliğe gidilerek kış tatil köyleri de faaliyete başlar. Akdeniz ülkeleri dışındaki ilk tesis, Tahiti'de açllır (1965). Bu ülkeyi Karayip Adaları ve Florida takip eder. Kuruluşunda daha çok bekârları ve genç çiftleri ağırlamayı hedefleyen Club Med, ilk Mini Club bölümünü açarak daha çok aile gruplarına yönelmeye başlar (1967).

Kar amacı gütmeyen birlik statüsünden kar amaçlı limited şirket statüsüne geçer (1965). “Üyelik müşteri” sistemi de devam eder. 1990'1 yıllar sıkıntılı geçer. Rakipleri, Club Med konseptini kopyalamaya başlar. Tatilciler, daha farklı ürünleri talep etmeye başlar. Baba Trigano yerine yönetime giren oğul Serge Trigano kısa süre sonra görevinden ayrilır (1993-1997). 2000'li yılların ilk başlarında yeni bir strateji geliştirilir. Tatil köyü kavramına yeniden dönülerek üst ve aile odaklı pazar hedeflenir. Kuzey Amerika k1tasındaki tesisler kapatılır (2005). Kısa bir süre için en büyük ortağı Accor firması olur (20042006). İzleyen 2006 ve 2007 yıllarında bazı tesislerin kapanmasına devam edilir, bazıları da yenilenir. Bazı yeni tatil köyleri açılır (2007-2008). Sonrasında Çin pazarına girilerek beş tesis sahibi olunur. O dönem yaratılan "mutluluk dünyayı yakaladığında" sloganı günümüzde halen kullanılır (2008). Misafir kitlesinin büyük bir kesimini aileler oluşturur; bunu çiftler ve bekârlar izler. Daha çok egzotik bölgelerde kurulan tesis, 2004 yılında yeniden gözden geçirdiği "herşey dahil" konsepti ile faaliyetlerine devam eder. Dünya genelindeki 71 tesisinde toplam 110 ülkeden yakla-

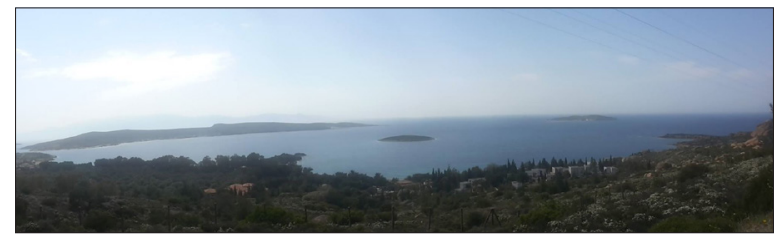

Fotoğraf-1. Koydan bir genel görünüm 
şık 13,000 çalışanı görev yapar. 40 ülkede operasyona sahiptir. En son sahibi, Fosun International isimli firmadır. Merkezi, Paris'tedir.

\section{FOÇA CLUB MED TATIL KÖYÜ: GELIŞiMi VE SONUÇLARI}

Yukarıda da kısaca değinildiği gibi; 1960'1 yıllar, Club Med firmasının ürün çeşitliliğine gittiği ve dünyaya açıldığı bir dönemdir. İlk tesisini Tahiti'de açmakla birlikte, başka ülkelerde de hizmet verilmesi konusunda isteklidir. Türkiye'de ise, T.C. Turizm ve Tanıtma Bakanlığ turizm resmi anlamda kamusal bir kimlik kazanmış olur. 1963 yılından itibaren Devlet Planlama Teşkilatı tarafından hazırlanan Beş Yıllık Kalkınma Planlarında turizm sektörüne önem verilmesi vurgusu yapılır. Yabancı sermaye konusundaki çalışmalar önem kazanır. Böyle bir ortamda Club Med'in Türkiye'ye geldiği süreci, o dönem T.C. Turizm ve Tanıtma Bakanlığg'nda görevli olan Mukadder Sezgin (2016) şu şekilde açıklar:

Şimdi onun ilk kurucusu, sahibi ve Yönetim Kurulu Başkanı Gérard Blitz isimli, filozof kafalı, yaptığı işin ekonomik, sosyal ve kültürel boyutlarıyla dünya turizmi için taşıdığ 1 anlam ve önemin bilincinde olan bir insandı. Onu davet ettik, Türkiye'ye ilgi duyuyorlarmış ki, hemen davetimizi kabul edip geldi. Kendisiyle konuştuk, Türkiye'nin turizm açısından önemini anlattık. Yatırımcı olmaktan çok işletmeci olarak çalıştıklarını, yatırımcının da, hiç değilse kısmen bir devlet kurumu olmasına özen gösterdiklerini belirtti. Devletle işbirliği hâlinde çalışmanın kendileri için hem yatırım hem işletme dönemleri bakımından güven verici bir durum yarattığını; öncelikle de, ülkemizde bu imkânın var olup olmadığını bilmek istediğini söyledi. Kendisine, bu sektörde gerçekleştirdiği yatırımlarla, bilgi ve deneyimiyle öne çıkan kurumun Emekli Sandığı olduğunu belirttik. Onun gerçekleştirdiği Hilton ve Tarabya otellerini, inşa edilmekte olan Büyük Efes otelini örnek gösterdik... (s.322).

Sezgin, Blitz ile yapılan görüşmelerin devamında Türkiye'nin turizm sektörüne ayıracağ kaynağın kısıtlı olduğunu, kendisine ulusal bir firmayı ortak olarak almasını önerir. Blitz, ileride sorun çıkabileceği konusundaki endişesini dile getirerek bu öneriye sıcak bakmaz. Daha önce bir başka Fransız inşaat firmasının Türkiye'de yaptı$\breve{g}_{1}$ faaliyetlerin takibini üstlenen Transtürk firması ile yine takipçi olarak çalışılmasına karar verilir. Blitz, T.C. Emekli Sandığı ile çalışma fikrine

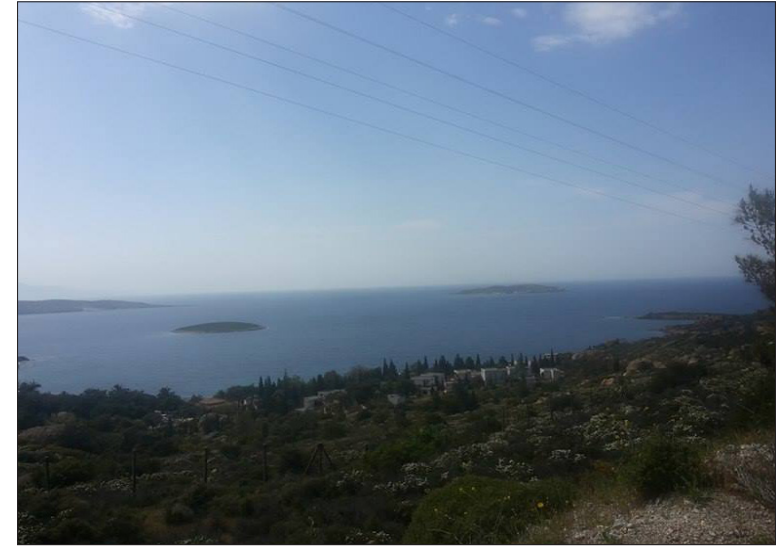

Fotoğraf-2. Koydan bir genel görünüm

sıcak bakar. O dönemde T.C. Emekli Sandığı' nın bağlı olduğu Maliye Bakanı Ferit Melen ile görüşmesi sağlanır. Blitz, Melen'e, İkinci Dünya Savaşı sonrası dünyada meydana gelen değişimlerden yola çıkarak Club Med misyonunu anlatır. Bu görüşmenin içeriğini Sezgin (2016) şöyle anlatır:

... nüfus hareketlerinde, kentleşmede görülmemiş değişim ve dönüşümlere yol açtığından bahisle sözü turizme getirdi. Özetle, yoğun ve kitlesel boyutta sürüp giden kent yaşamından bunalmış insanlara Fransa içinde ve dişında, doğayla bütünleşerek dinlenme, eğlenme, toparlanma imkânları sunacak nitelikte, kendi tasarımlarına göre inşa ettirip işlettiklerini belirterek Türkiye'de de bu tür köyler kurmayı istediklerini; bunların, doğal çevre ile uyumlu, toprak, kerpiç, ahşap, saz, kireç v.s. gibi malzemelerle yapılmış bungalovlardan oluştuğunu; bu konutların sadece uyku için kullanılmak üzere tasarlandığını, günlük yaşamın açık alanlarda yeme-içme, spor, eğlence, kültürel etkinlikler, dans ve oyunlarla geçirildiğini; zaman zaman da dünyaca ünlü, örneğin Jean-Paul Sartre gibi fikir ve düşün adamlarının, yazar ve sanatçıların, eleştirmenlerin davet edilerek onlarla konferans, konser, sohbet, tartışma gibi etkinliklerin düzenlendiğini, yerel halkın folkloru, el sanatları gibi geleneksel kültür ürünlerinin sergilendiğini, ülke içi geziler düzenlendiğini, bu tür deneyimleri yaşamış olan turistlerin ülkelerine mutlu döndüklerini ballandıra ballandıra anlattı. Fas'taki Agadir Tatil Köyü'nü, Fas Kralı Hasan'ın turizme verdiği önemi övdü. Ayrıca, tesislerinin bulunduğu ülkelerin ilginç doğal ve kültürel zenginliklerini tanımak üzere geziler düzenlediklerini, yeme-içme, giyim kuşam, el sanatları, folklor, müzik, dans gibi geleneksel kültürel değerlerinden örnekler sergilediklerini, farklı kültürler arasında karşılıklı alışveriş, birbirini tanıma, anlama, yakınlaşma yoluyla uluslararası barışa katkıda bulunmaya çalıştıklarını anlattı. Ferit Bey, "Mukadder, bu adamın anlattıkları rüya gibi şeyler... Çok hoşuma gitti. Ne lâzımsa yapalım; şimdi size Emekli 
Sandığı Genel Müdürü Muzaffer Bey'e göndereyim, onunla bir görüşün," dedi ve ona telefon ederek konuyu kısaca anlatarak bizi kabul etmesini sağladı... (s.322).

T.C. Emekli Sandığ 1 Genel Müdürü Muzaffer Emre, konuya sicak bakar. 1964 yılında Club Med, Ege Bölgesi'nde bir tatil köyü projesi için arazi incelemesi yapar. Önce Muğla-Dalyan İztuzu sahili için teklif gelir. Blitz, antik kentlere, İzmir'e ve havaalanına yakınlığı, turizme elverişli konumu, doğa güzelliği ve kruvaziyer gibi özellikleriyle oldukça tanınmış bir yerleşim yeri olan Kuşadası üzerinde durur. Uygun arazinin bulunması ve etütlerinin yapılmasına karar verilir. Dilek Yarımadası'nda yer alan Küçük Kalamaki seçilir. Ancak burası milli park ilan edileceği için vazgeçilir, Aslanburnu seçilir. T.C. Emekli Sandığı, bu arazinin mülkiyetini alır. O dönemde şirkete ortak olan Mösyö Trigano, ünlü mimarlardan Jean Weiler ile Ankara'ya gelir.

Haberi alan dönemin Belediye Başkanı Selçuk Dirim, İzmir Valisi ile görüşmeler yaparak Fransız heyetini Foça'ya davet eder. Maliye Bakanlığı'nda görevli Foça hemşehrisi Akif Kinşan, ekibe Foça'yı da görmelerini tavsiye eder. Club Med'in kurucusu Mösyö Trigona, Selçuk Dirim ile birlikte Foça'da tatil köyünün yerini belirlemek için helikopter ile keşif uçuşu yaparken şu anda kurulu olan alanı beğenir. Selçuk Dirim, tesisin bu arazi üzerinde kurulması durumunda yerel yönetim ve halk olarak gerekli desteği vereceklerini ifade eder. O dönemlerde Foça'da faaliyet gösteren sadece küçük ölçekli iki adet ko-

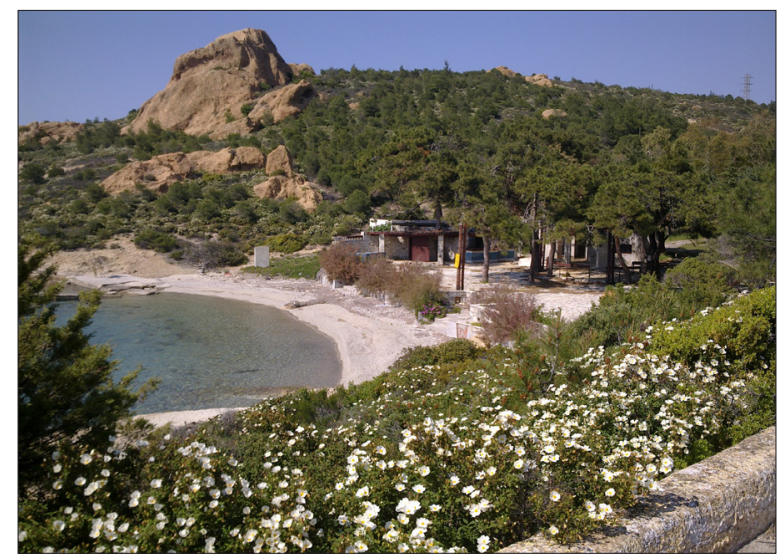

Fotoğraf-3: Plaj-1 naklama tesisi bulunur: Kaan Otel (5 odalı, sahibi Esat Kaan) ve Pansiyon1 (12 odalı, Ferit Oğuzbay-Köy Enstitüleri kurucularından öğretmen ve müfettiş). Bu nedenle, Club Med'in yöre turizminin ve ekonomisinin gelişiminde ciddi ölçüde katkıda bulunacağı düşünülür.

Trigano, Kuşadası yerine Foça'yı tercih ettiklerini söyler. Gerekçe olarak Marsilya'nın Foça ile bağını gösterir (Marsilya, Antik çağda Pers hâkimiyeti altında kalmak yerine ülkelerini terk eden Foçalılar tarafından kurulur); bu nedenle, Fransızlar için daha çekici olacağını söyler. Ancak Trigano, ortaya çıkacak yüksek maliyet ve sonrasında kendisinden istenecek yüksek kiradan kaçınmak için düşük kaliteli bir tesisin yapılmasında israr eder. Bu düşünce, Muzaffer Emre tarafından kabul görmez ve anlaşmazlık ortaya çıkar. Muzaffer Emre, yüksek nitelikli bir inşaat düşüncesinden yanadır. Ortaya çıkan anlaşmazlı̆̆ın ve sonrasındaki çözümün içeriği hakkında Sezgin (2016) şu bilgiyi verir:

... Emekli Sandığı'nın kira için belirlediği rakamı aşırı yüksek bulduğunu ve bu durumda projeden vazgeçeceklerini söyleyerek ayağa kalkıp toplantıy1 terk edeceğini belirten Trigano'ya, Muzaffer Bey şöyle cevap verdi: "Bu hareketinizi tasvip etmiyorum. Benimle görüşmeye geldiniz, sizleri kabul ettim. Taleplerinizi kabul etmek veya etmemek yetkisinde olan bir kişi varsa o kişi benim. Buyurun, şimdi gidebilirsiniz. Ben dosyayı burada kapatıyorum." Trigano neye uğradığını bilemez duruma düştü; özür dileyerek yerine oturdu ve görüşmeler yeniden başladı. Muzaffer Bey yetki ve sorumluluklarının bilincinde, konusuna hâkim mükemmel bir müzakereciydi. Çetin tartışmalardan sonra anlaşma imzalandı. Böylece Foça'da betonarme olarak, her biri en az bir zeytin

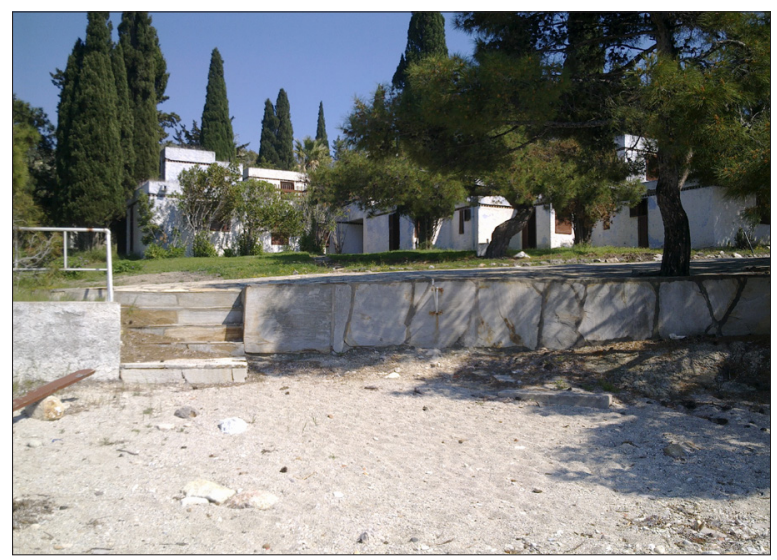

Fotoğraf-4: Plaj-2 


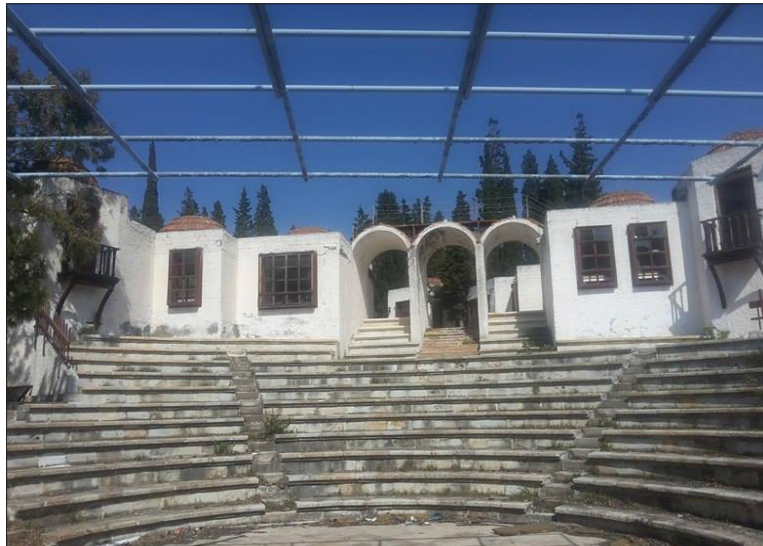

Fotoğraf-5. Ortak alan (Amfi Tiyatro)

ağacına sahip, araziye geniş aralıklarla serpiştirilmiş bungalovlar ve ortak donanımlardan oluşan bir tatil köyü yapıldı ve işletmeye açldı... (s.323).

Muzaffer Emre, Mösyö Trigano ve Selçuk Dirim, tesisin açılması için birlikte girişimde bulunur (Sezgin 2016). Hazineye ait arazinin kamulaştırılması görevini T.C. Emekli Sandığı üstlenir. Foça Belediyesi kendine ait araziyi bağışlar. Hazine, kendine ait kısımları bedelsiz devreder. Orman İdaresi'ne ait arazi kiralanır. Şahıs arazisi, bedelinin altında satın alınır. Bir bakıma Devleti ve halkıyla özverili bir işbirliği projesinin örneği sergilenir. Tesisin mülkiyeti T.C. Emekli Sandığı'na, işletme hakkı da Club Med firmasına ait olacak şekilde, Mösyö Trigano 10 yıl süreyle kiralama yapar. Projesi, Fransız mimarlar tarafından çizilir. Gece geç saatlere kadar devam eden inşaat aşamasında Fransız mimarlar ile Türk çalışanlar arasında iletişimin sağlanması için o dönem Foça Ortaokulu'nda Fransızca Öğretmeni olarak görev yapan bir kişi de (Gentil Organisateur sıfatıyla), tercümanlık yapar.

Dönemin T.C. Turizm ve Tanıtma Bakanlığı'nda görev üstlenen Adnan Özaktaş (2016), Club Med'in Türkiye'ye gelişini ve Foça tesisinin mimari çizimini şu şekilde açıklar:

\footnotetext{
... O zaman ne yapalım dedik, Hilton'u herkes örnek alıyor çizerken. Ondan sonra tatil köyünde örnek yok. O ara Emekli Sandığı da turizm yatırımı yapıyor. Hilton'u yapan Emekli Sandığı biliyorsun. Kuşadası'yla Foça'da, Club Mediterranee; bunlar tatil köyü kurmaya istekli olarak Türkiye'ye geldiler, ben aracı oldum. Emekli Sandığıyla onları ortak yaptık. Zarar etti Emekli Sandığı ama kasıtlı ola-
}

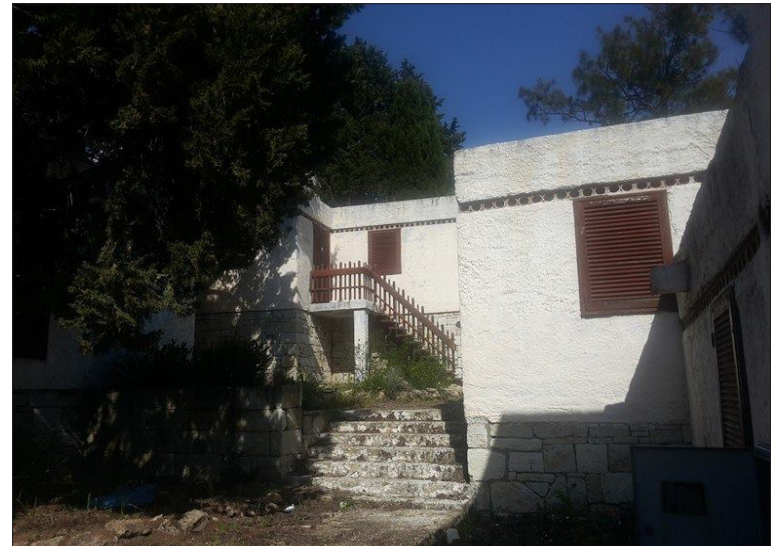

Fotoğraf-6. Odalar

rak 'Türkiye'ye bunlar gelsin' diye bazı avantajlar sağladık. Club Mediterranee, onlar da bayıla bayıla geldiler. E onların biliyorsunuz, kampçılık konusunda büyük deneyimleri var. O zaman dünyanın en iyi kamplarını Club Mediterranee yapıyordu. Onlardan iki tane yaptılar. Biz mimarlara dedik ki 'Isşte örnekler.' O zaman modaydı deniz kıyısında şeyler yapmak, tatil köyleri yapmak. Öyle lüks otel değil onlar, böyle ayrı ayrı oluyor. Neyse bizimkiler de başladılar çizmeye tatil köyü projeleri ve böylece yatırım bir ölçüde şekillenmeye başladı... (ss.18-19).

1964 yılının sonunda T.C. Emekli Sandığ 1 inşaata başlar. Alınan izinle inşaatın son aşamalarında Foça Açık Tarım Cezaevi tutukluları çalışır (tesisin açılmasıyla birlikte tutukluların bahçe ve temizlik gibi işlerde çalıştırılması devam eder. Tesis yönetimi, işçilik gideri olarak Cezaevi Döner Sermaye İşletmesi hesabına belirli bir ücret ödemede bulunur. Bu ücret, tutukluluk bitiminde her işçiye ödenir). Club Med, sonradan kiradan düşülmesi şartıyla inşaat aşamasında nakit desteği verir. Yol, su ve elektrik gibi altyapı yatırımlarının tamamlanması konusunda Foça Belediyesi girişimde bulunur. Yolun geçeceği güzergâhtaki birçok arazinin sahibi bedel almaksızın arazilerinin devrini sağlar. İl İmar Müdürlüğü altyapı çalışmalarını, karayolları da yolun asfaltını tamamlar. Elektrik bağlantısı konusunda İzmir milletvekillerinden destek istenir. Halktan birinin arazisinde kendi onayıyla iki içme suyu kuyusu açılır. Bağarası Köyü'nde sondaj kuyuları açılır. Club Med sayesinde 1967 yılı başlarında Foça şehir merkezine elektrik ve su hizmeti de verilmiş olur. Öncesinde ise, benzin ile üretilen elektrik, sadece günün belirli saatlerinde şehre verilir. 
Tesis, 1967 yılının Mayıs ayında ilk misafirlerini ağırlar. Dönemin T.C. Turizm ve Tanıtma Bakanı Nihad Kürşad açılışını yapar. Selçuk Dirim, tedavisi nedeniyle İstanbul'da olduğu için açılışa katılamaz. Ancak 1997 yılında tesisin 30. yılı kutlamaları çerçevesinde İstanbul'da düzenlenen bir resepsiyonda Mösyö Trigano, oğluna bir teşekkür plaketi sunar (Katılımcı 4). Hürriyet Gazetesi'nde yer alan bir habere göre (2008), aynı uçakla İzmir Çiğli Havalimanı'na iniş yapan bir Fransız uçağından inen zengin turistler Club Med'e, diğerleri de Foça'daki diğer otel işletmelerine yönlendirilir. Tesis, ilk beş aylık dönemde istihdam ettiği 120 kişilik çalışan ekibiyle toplam 900 Fransız turiste hizmet verir. Foça ilçe merkezine $5 \mathrm{~km}$ uzaklıktaki tesis, Türkiye' nin ilk tatil köyü ve aynı zamanda "çıplaklar kampı" unvanına da sahip olur. Önce Foça, sonrasında Kuşadası açılır. Foça'nın önemli işadamlarından olan Reha Midilli ve ailesinin yaşamını anlatan bir kitapta tesisin kuruluş yıllarına ve sonrasında Foça ekonomisine katkısına vurgu yapılır (Yiğit 2012, ss. 300-301):

Artık çürümeye terk edilen Foça Tatil Köyü'nün, yurdumuzun turizm tarihinde önemli bir yeri vardır... Yöre insanları için iyi bir işyeriydi. 141 bin 380 metrekare araziye kurulu yurdumuzun ilk tatil köyü, zamanın Turizm ve Tanıtma Bakanı Nihad Kürşad tarafından yaptırılmış ve 1967 yılında Foça Fransız Tatil Köyü "Club Med" adıyla hizmete girmişti. Bu yıllarda günümüzün seçkin tatil yöresi Antalya'ya ulaşmak bile zordu. Foça Tatil Köyü'nün inşaatında o zamanki adıyla Foça Açık Tarım Cezaevi'nin hükümlülerini çalıştırmıştı. Foça Tatil Köyü hizmete girdiğinde; domatesinden, kavununa, yumurtasindan, balığına kadar pek çok gıda maddesini yine cezaevi karşılamıştı. Hatta kulübün barlarından restoranına varıncaya dek hükümlüler görevlendirilmişlerdi.

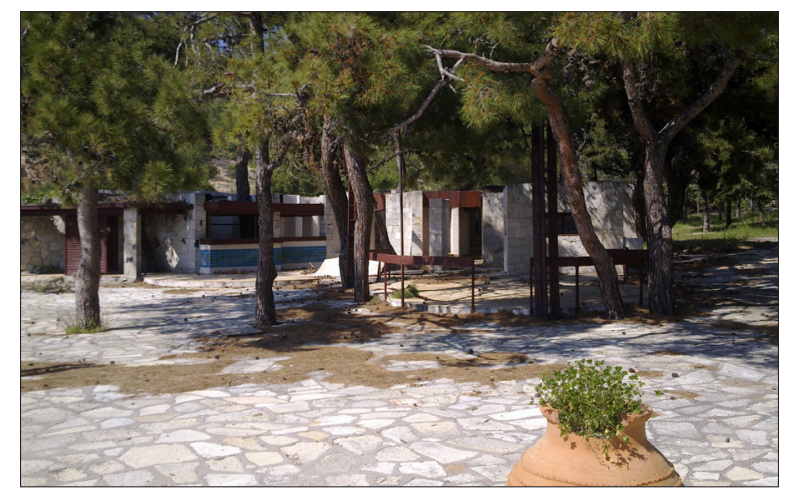

Fotoğraf-7. Ortak mekan
Toplam 141.380 metrekare büyüklüğündeki tesisin 1982 yılında sözleşmesi tekrar uzatılır; 2005 yılında da hizmetine son verilir. Hizmetine son verilmesinin gerekçesi, Club Med firması tesisin yıprandığını ve bakıma alınmasını ister. Ancak T.C. Emekli Sandığı yönetimi, ortaya çıkacak maliyeti göz önünde bulundurarak teklife sıcak bakmaz. Firma yönetimi de, işletmeyi bırakır. Yukarıda da değinildiği gibi, izleyen iki yıl içinde farklı ülkelerdeki diğer tesislerin faaliyeti de durdurulur. Mülkiyet hakkı, T.C. Emekli Sandığı'na ait olan tesisin günümüzdeki durumu ile ilgili çeşitli tartışmalar devam etmektedir. Bir kesim, tesisin mülkiyetinin kamu tarafından satın alınarak yeniden işletmeye açılmasını isterken, bir başka kesim de kiralama ya da satış yoluyla özel sektöre devredilerek faaliyetinin devamlılığını istemektedir. Nitekim 2005 yılında özelleştirme yoluyla satışa çıkarılan tesis 8,2 milyon Doları bedelle alıcı bulur ancak Devlet onayı alınamaz (Hürriyet 2008). 2007 yılında T.C. Emekli Sandığı'ndan Hazine'ye devri yapılan Club Med tesisi ve arazisi, 2010 yılında İzmir Defterdarlığı tarafından satışa çıkarılır ancak bu kez alıcı bulamaz.

\section{Özellikleri}

Her yılın Nisan ayının sonunda faaliyetine başlayan tesis, aynı yılın Ekim ayı sonlarında sezonu bitirir. Bir bakıma sadece yaz sezonunda "denizkum-güneş" üçlüsüne dayalı hizmet veren tesis özelliğine sahiptir. Tesis, 800 oda kapasiteli olarak faaliyetine başlar. Tesisin içinde "Arap Köyü" ve "Türk Köyü" diye iki bölüm yer alır. Her odanın "araba" gibi nesneleri ya da "kedi" gibi canlıları çağrıştıran ve alfabetik sıralanan Türk-

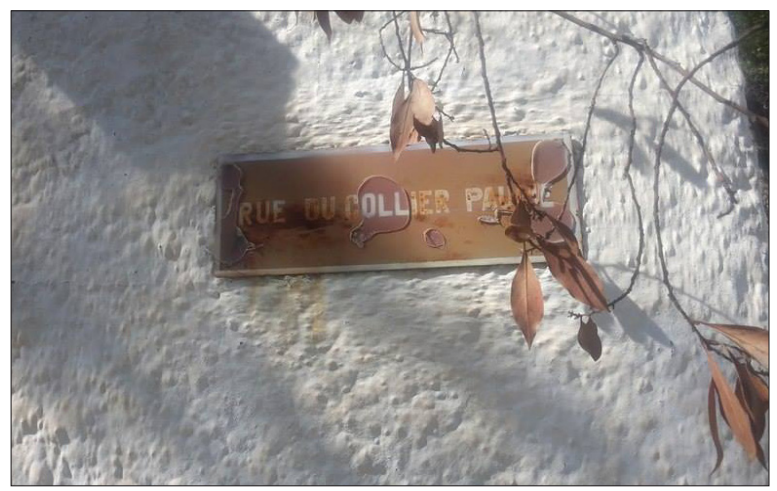

Fotoğraf-8. Sokak isimleri-1 


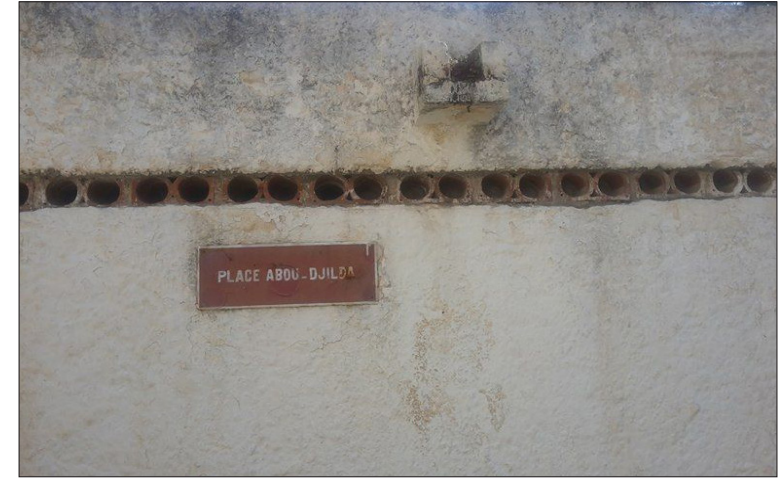

Fotoğraf-9. Sokak isimleri-2

çe bir ismi olur. Amaç, misafirlerin birkaç kelime Türkçe öğrenmelerinin teşvik edilmesidir. Odaların pencereleri küçük ve içi loş olarak tasarlanır, serpme sıva kullanılır. Gerekçesi de, misafirleri mümkün olduğunca oda dışında tutup aktivitelerden yararlanmalarını teşvik ederek satış hacminin arttırılmasıdır. Bu aktiviteler arasında Türk hamamı ve iki adet açı olimpik yüzme havuzunun yanı sıra yelken, okçuluk, tenis, su kayağ1 ve dalış yer alır. Çocuk havuzu yoktur. Her akşam yemek sonrası tiyatroda çeşitli eğlence ve gösteriler düzenlenir. Gece barı ve disko saat 04.00 'e kadar açık kalır. Gece barında mangal partileri yapılır. Odalardan uzak konumlandırıldığı için disko rahatsız edici olmaz.

Tesis, tam pansiyon sistemiyle çalışır; ekstra yiyecek ve içecekler için önceden satışı yapılan renkli boncuklar kullanılır. Sonraki yıllarda "ticket" uygulamasına başlanır. 1983 yılından önce alakart servisi yapılırken, sonrasında sadece kahvaltıda açık büfe servisi başlar. 1985 yılından itibaren üç öğün için de açık büfe servisi başlar. Tesisin çeşitli ülke yemeklerinin hazırlanıp sunulduğu uluslararası bir mutfağ 1 da bulunur. Restoranlarda sekiz kişilik masalar yer alır. Yemek yanında genellikle limitsiz miktarda Türk şarabı servis edilir. Ortalama konaklama süresi bir hafta ile iki ay arasında değişir. Ulaşım, Çiğli Askeri Havalimanı üzerinden sağlanır. Turistlerin geliş yaptığı günlerde, bazı departman yöneticileri havalimanına karşılamaya gider; tesis içinde de ayrıca bir karşılama yapılır.

Tesisin faaliyetlerini yerine getirebilmesi için izlemiş olduğu örgütlenme modeli şu şekildedir:

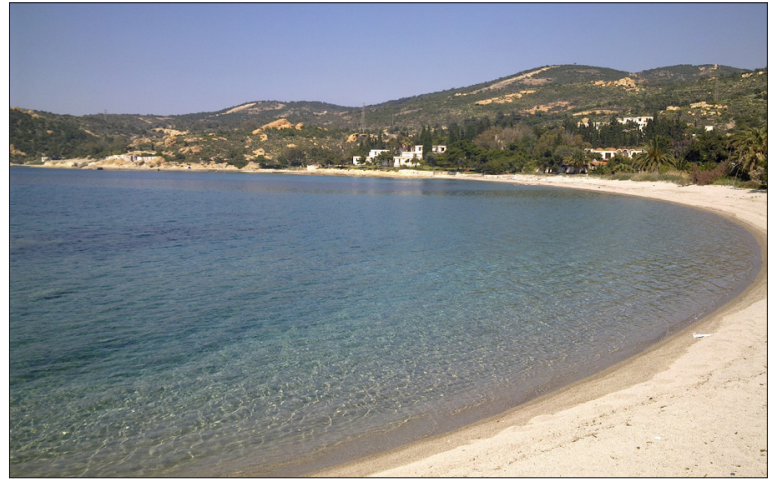

Fotoğraf-10. Plaj

Üst yönetimde iki müdür bulunmaktadır. Bunlardan biri yönetim işlerinden, diğeri animasyon hizmetlerinden sorumlu olup, eşit statüye sahiptir. Tesis müdürüne bağlı görev yapan muhasebe (gestion), resepsiyon, halkla ilişkiler, gezi bürosu, satın alma ve mal kabul (economo), teknik servis (material), oda temizleme hizmetleri, restoran, gece ve gündüz barları. Tesisin yöneticisi hep Fransız olmakla birlikte, departman yöneticileri farklı ülkelerden oluşur. Tesis yöneticisine "Gentil Membre" (G.M.), departman yöneticilerine de "Gentil Organisateur" (G.O.) adı verilir. Bir Fransız sömürgesi olan Tunus ve Fas gibi ülkelerin yanısıra başka ülkelerden de çalışanlar görev alır. Tesis çalışanları ile misafirlerin birlikte yemek yiyerek, dans ederek ve spor yaparak zaman geçirmesi serbesttir (Çalışan-misafir arasındaki bu tür uygulamaları 2000'li yıllarda Valtur İtalyan Tatil Köyü de izler).

Tesis yönetimi ile Foça Belediyesi arasında yapılan bir sözleşmeyle, şef dışındaki diğer çalışanların Foça yöresinden olması şartı getirilir. Çalışanlar ile ilgili sorunların çözümünde Belediye aracılık ederken, Fransızca Öğretmeni de bu anlamda tercümanlık görevini üstlenir. İlk iki yıllık dönemde sadece iki kadın görev almak ister ve yaptıkları işten memnun kalır. 1969 yılından itibaren daha fazla kadın çalışan başvuruda bulunmaya başlar. İlk görev yeri burası olan bazı çalışanlar zamanla yetişip şef unvanına yükselir. Bakım-onarım, yelkencilik gibi işleri ilk yıllarda Fransız çalışanlar yerine getirirken, bu tür işler ilerleyen yıllarda Türk çalışanlara devredilir. Güman Kızıltan (2016), yöre insanlarının istihdamı 
konusunu şu şekilde açıklar:

Foça Tatil Köyü'nü açtı̆̆ 1 zaman eleman bulmakta sıkıntı çekti, çünkü Foça'nın halkı öyle çalışmaya alışık değil, nüfus da az, köyler var yanında köylerde de şey etti. Bunlar 1srarla bu çocukları tatil köyünde çalışmaya aldılar garsonluktan tutun temizlikçiliğe kadar. İşte tabi eğitimli elemanlar olmadıkları için bir başka üst göreve gelmeleri mümkün değil. Yahut da işte sportif faaliyetlerinde, işte gece kulüplerinde şunlarına bunlarına aldılar ve bunları eğittiler. Oraya gelen gençler iki ve üçüncü yılın sonunda dünyadaki Club Mediterranee tatil köylerinde görevlendirildiler, müdürlüğe kadar yükselen insanlar oldu. Onun için bu öncü tesisler var ya ilk kurulan, bunların hepsi aynı zamanda bir okuldu, pratik okullar... (ss. 185186).

Fransız çalışanlar 12 ay istihdam edildikleri için sezon bitiminde zincirin Fransa ya da İsviçre'de bulunan diğer tesislerinde istihdam edilir. Zincirin İsviçre'deki kış tesisinde görev alan gruba, bazı Türk çalışanlar da dahil olur. Bir katılımcı, yılını anımsamadığı bir yaz sezonunda tesisin açılmadığını ve çalışanların o yıl zincirin İsrail'deki tesisinde görevlendirildiğini söyler (Katılımc1 2).

Tesis, ilk açıldığ lere hizmet verir. Animasyon gösterileri Fransızca dilinde yapıldığı için ilk yıllarda Türk misafir kabul edilmez. Sadece özel misafirlerin girişine izin verilir. Bunlar arasında 1970'li ve 1980'li yıllarda Ajda Pekkan, Nükhet Duru, Müzeyyen Senar, Neco gibi isimler yer alır. Bu ünlüler aynı zamanda Uluslararası İzmir Fuarı için gelir, tesiste konaklar ve bu sırada da ayrica konserler verir. Ünlü misafirler arasında Sakıp Sabancı da yer alır. Tesisin, zamanla Almanya ve İngiltere başta olmak üzere Avrupa'nın diğer ülkelerine açılmasiyla birlikte, Türk misafir yasağ 1 da tamamıla ortadan kalkar. Tesis, birçok edebi ve sanatsal etkinliğe de ev sahipliği yapar. Felsefe konferansları yapılır, sanatçılar ve şairler davet edilerek söyleşi yapmaları teşvik edilir. Hatta Fransa'dan davet edilen bir uzmanın, Türk halıcığı konusunda konferans verdiği de bilinmektedir.

Aşağıdaki alıntıdan da görüleceği gibi, Club Med Foça, bazı uygulamaların yerleştirilmesi konusunda ulusal turizm sektörüne de örnek olur. Yemeklerde açık büfe uygulaması, alışverişte boncuk ya da "ticket" kullanılması, gündüz saatlerinde su sporlarını akşam saatlerinde de eğlen-

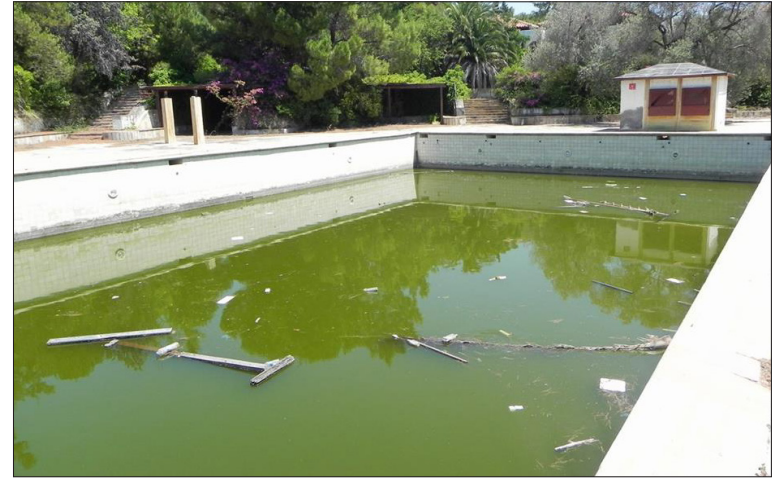

Fotoğraf-11. Ortak mekan (Yüzme Havuzu)

ceyi kapsayan animasyon gösterileri ile Türk turizmine birçok konuda ilk olma özelliğini kazandırır. Tesisin alışveriş merkezinin de, o dönemlerde oldukça gözde olduğu dile getirilir (Doğan 2010). Günümüz herşey dahil sisteminin temelini oluşturan su sporları ve animasyon gibi etkinliklerin yer alması, 800 gibi yüksek oda kapasitesiyle geniş bir mekana yayılan tatil köyü modelinin ortaya çıkması, 1980 ve 1990 'lı yıllarda, para yerine kullanılmak üzere misafir tesise giriş yaptığ1 andan itibaren kullanmak zorunda olduğu ancak sonradan kullanımdan kalkan "boncuk" ya da "ticket" uygulaması sayılabilir. Tesise ilk giriş yapan bir misafir, ya muhasebe bürosunda ya da Ziraat Bankası tarafından açlan seyyar döviz bürosunda parasını bozdurarak harcama için gerekli "boncuk" ya da "ticket" alır. Foça şehir merkezinde hiçbir zaman döviz bürosu görülmez.

\footnotetext{
Kesin tarihini anımsamamakla birlikte, 1968-1970 y1lları arasında iki gece burada konakladım. O dönem için çok ilgi çekici ve popüler bir yerdi. Genellikle Fransız turistler konaklıyordu. İlk herşey dahil sisteminin temelleri orada atıldı diyebiliriz. Odalar biraz loştu ve odada müşteriyi tutmamak için birçok sosyal ve sportif aktiviteler vardı. Eğlenceler, animasyonlar, yelken, su kayağı gibi. Otele giriş sırasında belli bir ücret karşılığında renkli boncuklardan oluşan bir kolye alınıyordu. Her renk farklı bir para yerine geçiyordu. İçerideki ekstra harcamalar bu boncuklarla yapılıyordu. Bunun dişında belli saatlerde ikramlar vardı. Çıplaklar kampı vardı fakat burası kapalı bir koydu. Bu bölümü görmedim. Dışarıdan görünmüyordu ve bu nedenle bir tepki oluşmadı. (Katılımcı 7).
}

Bir başka ilkler arasında, turizm sektöründe o yıllarda kendisini gösteren sendikalaşma hareketi yer alır. Çalışanlar bir yandan Belediye'nin garantörlüğünde işe alınarak görevlerini yerine 
getirirken; diğer yandan da, sendika üyesi olurlar. Tesisin faaliyet dönemi boyunca iki kez greve gidilir. Foça yöresinden istihdam edilen yerel halkın uzun yıllar tesiste görev yapmasında belediyenin ve sendikanın etkili olduğu dile getirilir.

\section{Çıplaklar Kampı}

Club Med, oluşturduğu çıplaklar kampı konseptiyle de dünyada ve Türkiye'de adından söz ettiren bir firmadır. Club Med Foça aracılığıyla, Türkiye'ye de ilk çıplaklar kampı konseptiyle giriş yapılmış olunur. Tesisin kuzeyinde yer alan küçük ve dışarıdan görünmeyen kapalı bir koy "çılaklar kampı" için seçilir. Tesisin içinden geçilir, isteyen çıplak bir şekilde denize girer ve koydan ayrılmadan üzerini tekrar giyinir. Havuz ya da diğer plajlarda mayo ve bikini şartı bulunur. Ortak alanlarda üstsüz gezen misafirler, çıplaklar kısmına gitmeleri için uyarılır. Çok tercih edilen bir kısım olmayan bu kamp, yine de, tesisin ismiyle öne çıktığı önemli bir alan olur. Yazılı basında kamp hakkında haberler yer alır ancak yöre halkı kampa yönelik olumsuz bir tepki göstermez. Nedenleri olarak ise, koyun ayrı ve tesis içindeki belirli kurallara göre yönetilir olması, yöre halkının tesisten kazanç sağlaması ve kampı önemli bir tehdit olarak algılamaması gösterilir. Bununla birlikte; eşcinsel misafirler, yöre halkının tepki gösterdiği konular arasında yer alır. Nedeni ise, bu misafirler ile görüşmek üzere İstanbul'dan eşcinseller gelmeye başlar. Yerel halk ve misafirlerden gelen tepkiler üzerine, yönetim eşcinsellerin tesise girişini yasaklar.

\section{Anıları}

Club Med Foça'nın açılışından itibaren ya da sonrası bir dönemde çalışmış ve halen Foça'da yaşamını devam ettirmekte olan bazı kişiler ile yapılan yüz yüze görüşmelerde bazı önemli anılara ulaşmak da mümkün. Katılımcılardan birisi, 1984 sezon bitiminde Çiğli Havalimanı'ndan üç uçak dolusu çalışanın kış sezonunda çalışmak üzere İsviçre'ye uçtuğunu ve bu yolculuğun kendisinin ilk uçak yolculuğu olduğunu söyler (Katılımcı 2). İlçede Fransızca konuşan tek kişi konumundaki diğer bir katılımcı, öğretmenlik görevi sırasında hem okulda hem de Halk Eğitim Merkezi'nde Fransızca öğretir. Emekli olduktan sonra tesiste çalışmaya başlar. Özellikle Foça yöresinden istihdam edilecek çalışanların seçiminde etkili olur. Tesisin halkla ilişkiler bölümünde tercüman olarak çalışır ve şehir içi ve dışı günlük ya da iki günlük düzenlenen birçok turun sorumluluğunu üstlenir (Katılımcı 6). Açıldığı ilk yıldan itibaren tesiste uzun yıllar fotoğrafçı olarak görev yapan Mehmet Yavuz (2011), şu anda emekli olmasına karşın, o yılları özlemle andığını ve tesis kapandığında hıçkırarak ağladığını dile getirir. Açllmasında etkin rol oynayan dönemin Belediye Başkanı'nın oğlu, Club Med Foça'nın 30. yıl anısına İstanbul Boğazı'nda düzenlenen resepsiyonda, vefat eden babasının yerine teşekkür belgesi aldığında yaşadığı duygusal anları hala unutamadığını söyler (Katılımcı 4).

\section{Toplumsal, ekonomik ve fiziksel sonuçları}

Birçoğu Foça'dan olmak üzere birçok personeli istihdam ederek yöre ekonomisine katkıda bulunan Club Med, aynı zamanda, yöre insanlarının eğitime ve dil öğrenme gibi toplumsal konulara da öncülük eder. Genellikle Fransızca bilen çal1şanların tercih edilmesi nedeniyle, ilçenin ortaokulunda görev yapan Fransızca Öğretmeni, gerek okuldaki derslerinde gerekse de Halk Eğitim Merkezi öncülüğünde açılan akşam dersleriyle gençlere ve halka Fransızca öğretmeye başlar (Katılımc1 6).

Foça'nın günümüz Belediye Başkanı olan Gökhan Demirağ' 1 n verdiği bilgiye göre; tesisin istihdam ettiği birçok kişi günümüzde emekli olarak halen Foça'da yaşamlarını sürdürmektedir. Yaklaşık 300 kişi, işletmenin başka ülkelerdeki

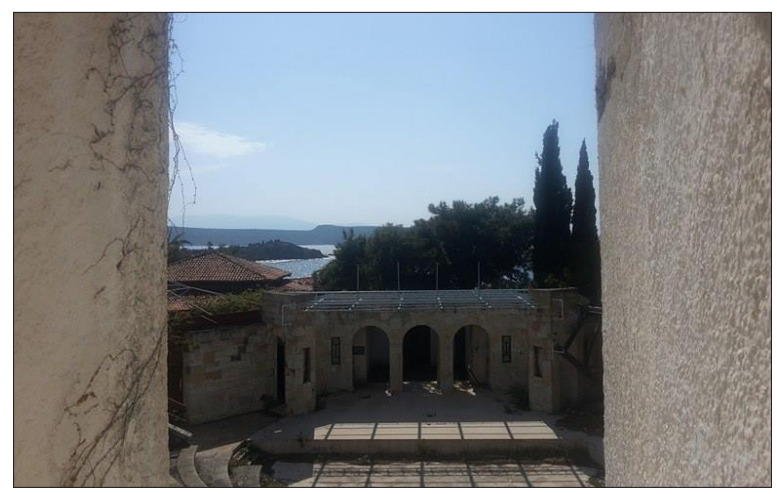

Fotoğraf-12. Ortak mekan (Amfi Tiyatro) 


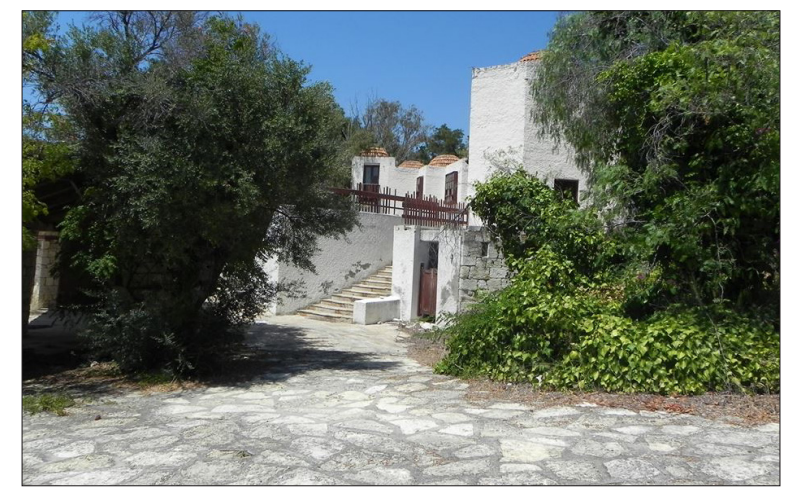

Fotoğraf-13. Odalar

tesislerinde çalışma fırsatı bulur. Club Med aktif olarak çalıştı̆̆ 1 yaz dönemlerinde Foça, yılda yaklaşık 10,000 misafiri ağırlar ve yöre esnafı da bu hareketlilikten kendilerine düssen payı rahatlıkla alır (Hürriyet 2008). Foça'nın bir yerlisi, tesisin Foça ekonomisi üzerindeki etkisini şu şekilde özetler (Katılımc1 1):

O dönemde iyi halıcılar, kuyumcular vardı. Taksiciler çok para kazandı. Turistler, her yere taksi ile gidiyordu. Kaliteli ve çok harcama yapan turistler geliyordu. Akşamları balık restoranları dolu oluyordu. Restoranlar, Bodrum'dan 1stakoz getirtiyorlardı. Daha önce salaş meyhane türü olan restoranlar gelişti ve daha iyi hizmet veren balık restoranlarına dönüştü. Bu şekilde, Foça'da balık restoranı kültürü gelişti.

Yabancı içkiler ithal edilirken, sebze gibi temel gıda ürünleri İzmir Hali, İzmir Gıda Çarşısı ve Foça Açık Tarım Cezaevi'nden karşılanır. Balık gibi deniz ürünleri için merkez, Foça olur. Istakoz, Bodrum'dan gelir. Zamanla balıkçılık gelişir; Türkiye'de ilk trata yasağı Foça'da uygulanmaya başlanır. Daha sonra trol ve girgır da yasaklanır. Kıyı balıkçılığı çekici hale getirilir. Şehir merkezindeki modern görünümlü balık restoranlarının geçmişinde dahi Club Med etkisi görülür.

Tesis dışı aktiviteler arasında kısa ya da uzun süreli turlar yer alır. En fazla bir haftalık olan uzun süreli turlar, daha çok Doğu illerine yapılır. oldukça yüksek doluluk oranı ile çalışıldığı için bu şekilde yeni gelecek konuklara yer açılmış olunur (Sezgin 2016). Gezi bölümü, günde iki kez şehir merkezine yarım günlük tur düzenler. Taşıma için otobüs ya da tekne kullanılır. Şehir merkezinde balık restoranlarına giden de olur, alışveriş yapan da. Efes, Milet, Didim, Afrodisias ve

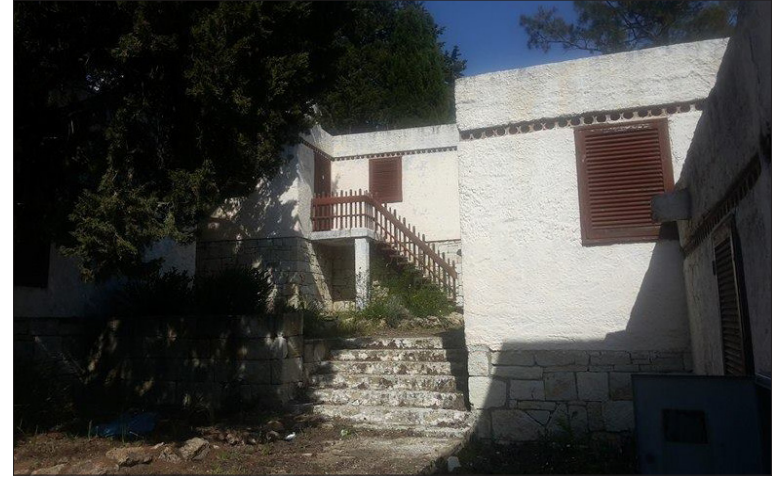

Fotoğraf-14. Odalar

Pamukkale gibi yörelere iki günlük; Bergama'ya günübirlik turlar düzenlenir. Ayrıca taksi kiralama yoluyla da benzer turlar misafirler tarafından planlanır. Hem tesis çalışanları hem de taksi şoförleri iyi bahşiş aldıklarını dile getirir ancak esnaftan komisyon alma kültürü o dönemde henüz yoktur (Katılımcı 6). Karşılayıcı ve tur düzenleyici amaçlı ilk acente, 1990'lı yılların başında açılır. NemTur isimli bu acente, 3,5 yıl faaliyet gösterir. Merkezi İzmir'de bulunan Bastıyalı isimli acente 1980'li yılların sonunda Foça'da bir şube açar, 1995 yılında da kapanır. İsveçli turistleri getirir. Halen Ampurya isimli sadece bir acente mevcuttur (Katılımci 1).

Annesi-babası ve kendisi olmak üzere aynı aileden iki kuşak tesiste görev yapar, yurtdışında çalışır, ekonomik olarak faydasını görür ve ev alır. Foça'nın yakın köylerinde yaşayanlardan seçilen çalışanlar servisle taşınır. Her Cuma günü özellikle bahçede yemek hazırlığı yapılır. Bu iş için ekstra görevli çalışır. Tesis yokken halkın geçimi sadece tütün ve balık iken, tesisin açılmasıyla birlikte turizm sektöründe çalışmaya başlar. Elde edilen gelir sayesinde arsa, araba ve traktör sahibi olanlar görülür.

Elde edilen ekonomik faydayla birlikte, ilçede entelektüel bir yaşam tarzı kendini gösterir. Esnaf ve halk, özellikle akşamları şehir merkezine gelen yüzlerce turist ile iletişim ve etkileşimde bulunur. İlçenin gençleri, daha iyi şartlarda yaşayabilmek için daha çok çalışır; eğitim düzeyleri artar. O dönemlerde liseden mezun olan hemen her genç belirli bir düzeyde Fransızca konuşur. Akşam saatlerinde yemek öncesi misafirler ile 
ilçenin gençleri arasında çeşitli sportif karşılaşmalarının düzenlendiği de olur. İlçede bir Fransız kültürü oluşmaya başlar; halk, Fransızlar gibi giyinmeye başlar (Katılımcı 6). Kavala, Midilli ve Limmi göçmenlerinden oluşan yöre halkının tutucu bir yapida olmamasının da, tesisle birlikte, halkın dışa açılmasında etkili olduğu dile getirilir (Katılımc1 4).

1963 yılında T.C. Turizm ve Tanıtma Bakanlığı'nın kurulmasıyla İzmir Bölge Müdürlüğü'ne atanan Güman Kızıltan (2016), tesisin Foça halkı üzerinden toplumsal değişimini şu şekilde özetler:

... Adamlar tam manasıyla maaşını veriyordu, tam
maaşıyla eğitimini veriyordu, adam gibi çalışma saat-
leri vardı, mesaileri vardı, dolayısıyla sektör sevildi.
İki en önemli şeyi söyleyeyim, bizim insanımız lokal
yaşayan insanlardı o devirlerde, yani Foçalı Foça'da
yaşıyor, Kuşadalı Kuşadası'nda yaşıyor bilmem ne,
gidip gelmeler çok az, İzmir'i bile görmemiş insanlar
var. Şimdi ilk önce bu tatil köyünü görüyor, o, ha-
yatında görmediği bir şey. Bir sürü insanlar geliyor
onlarla tanışıyor, çoğu orada lisan öğrendiler şakır
şakır. Ve onlar daha sonraki başka tatil köylerine,
kulübün dünyadaki diğer tatil köylerine eleman ola-
rak gönderildiler, sivrilenler tabii yani hepsi gönde-
rildi diye bir şey yok. Onun için bunlar çok önemli
değişim... (s.186).

İlçenin tarihindeki belki de en önemli etkinliği, 1968 yılında düzenlenmeye başlanan "Foça Müzik, Folklor ve Su Sporları Festivali" olur. Sponsorluğu Club Med tarafından yerine getirilen festival, zamanla ilçenin en önemli kültürel etkinliği halini alır. Bu konuda, o dönemde Foça

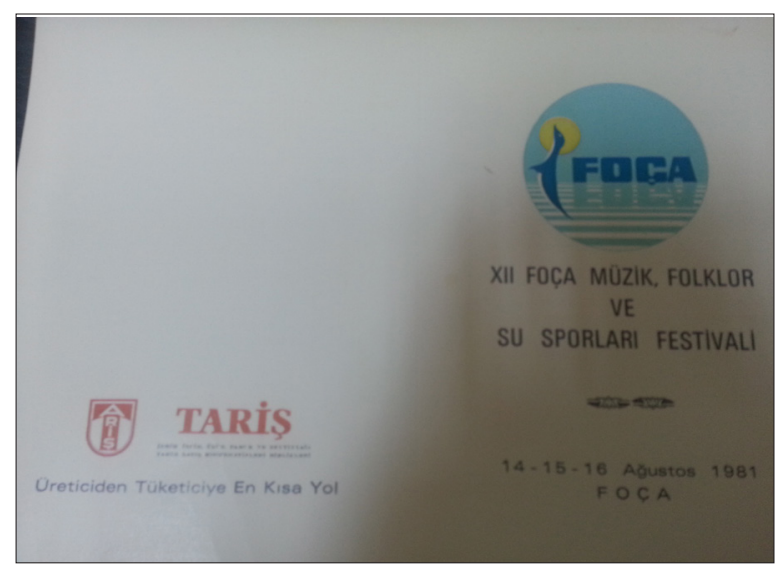

Fotoğraf-15. Festival davetiyesi
Belediyesi'nde memur olarak görev yapan kat1lımcı şu bilgiyi verir (Katılımcı 5):

Festival, 1968 yılında başlar. Öncülügüün̈ Kılıç Ali Aslan (İlçe Kadastro Müdürü), Abidin Aygün (İlçe Açık Tarım Cezaevi Müdürü), Ali Kaya (İlçe İlköğretim Müdürü), Süleyman Ege (İlçe Belediye Başkanı) ve Sibel Müstecaplıoğlu'nun yaptığ1 ekip, Yelken İhtisas Kulübü'nü kurar (1968). Bu kulüp, festivalin organizasyonunu üstlenir. İlk yıl, Müzeyyen Senar Gazinosu'ndaki seçmeler için İzmir'e gelen sanatçılar festivale de katılarak konserler verir. Tavuk çiftliklerinden nakit para, esnaftan erzak toplanır. Konaklama ihtiyac1nın karşılanması için okullar yatakhaneye çevrilir. İlçe halkı yemek hazırlar. Açılış davetiyeleri TARIŞ tarafından basılır (Foça merkezli Hüseyin Ulu ve Hüseyin Gen isimli Tariş yöneticilerinin girişimiyle). Club Med animasyon ekibi, tesiste akşam yemeğinden sonra sergiledikleri gösterileri (Speck Tag), festival kapsamında da tekrarlar. 1985 ile 1988 yılları arasında düzenlenmeyen festival, 1989 yılında "Balıkçılık Festivali" ile birleştirilerek bugüne kadar gelmiş olur. Günümüzde "Rastgele Turizm Foça Festivali" adıyla devam eden bir etkinlik olur.

Foça, yöresel kalkınma açısından elde edilen böylesine olumlu bir gelişme sonucunda Türkiye'nin diğer bazı destinasyonlarına da örnek olur. Örneğin; 1974 yılı yerel seçimlerinin kampanya çalışmaları sırasında Alanya Belediye Başkan Adayı "seçilirsem amacım, Alanya'yı Foça seviyesine çıkarmak olacaktır" sözünü verir.

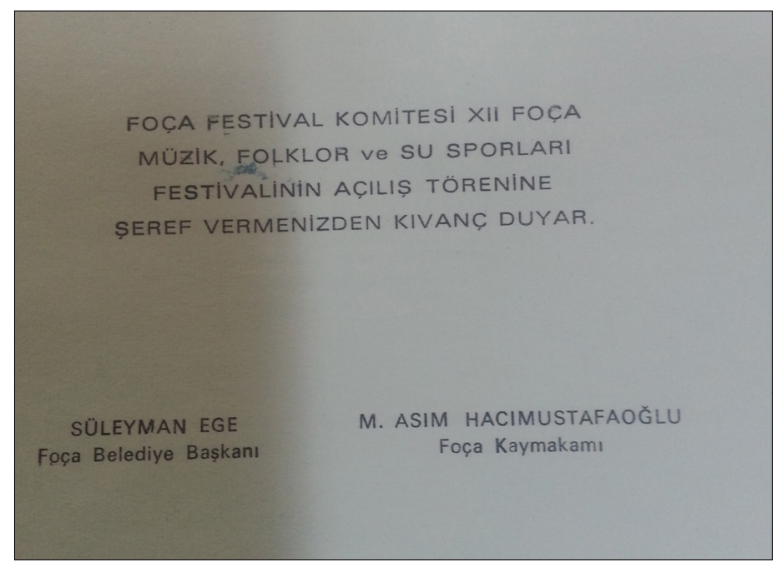

Fotoğraf-16. Festival davetiyesi-2 


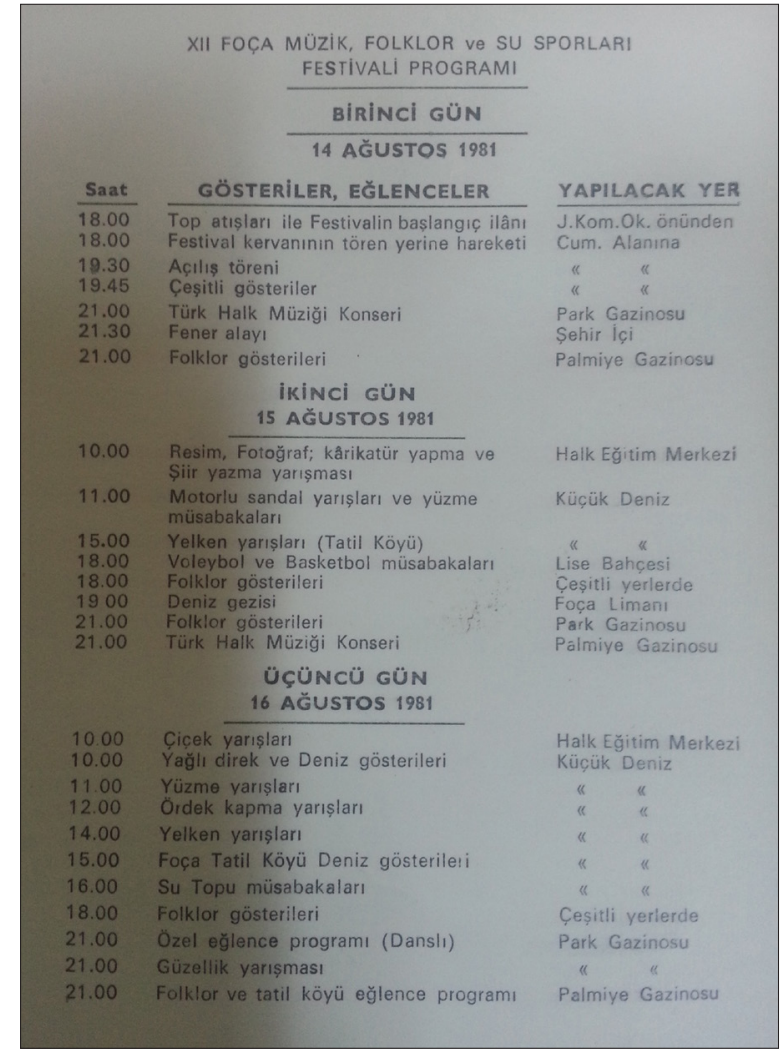

Fotoğraf-17 Festival davetiyesi-3

Günümüzle kıyaslandığında o günlerde olmasa da, Alanya'nın Foça seviyesine gelmesinden çok öte, Türkiye' nin çok önemli bir turizm destinasyonu haline gelmesi, bilinen ve inkâr edilemeyecek bir gerçeği oluşturur.

\section{Türkiye'de değişen turizm konsepti ve Foça Club Med}

Club Med, sahip olduğu 800 odası ve yaklaşık 140 dönümlük arazisinde sahip olduğu plaj1, spor tesisler, yüzme havuzu, Türk hamamı, tiyatrosu, ağaçları ile Türkiye'nin ilk tatil köyü özelliğine sahiptir. Bu tür özellikleri kendilerine "benchmark" kabul ederek, 1980'li yıllardan başlayarak oldukça fazla sayıda görmeye alıştığımız özellikle Akdeniz bölgesindeki tatil köyleri, bu başlangıcın bir devamı niteliğinde olabilir. Bu konudaki açıklayıcı bilgi aşağıda yer almaktadır:

... Tabi çok önemli. İşte ilk, bizleri biliyorsunuz Foça ve şeydeki Valtur, İtalyan tatil köyünden başka herhangi bir turistik kıyı tesisimiz yoktu. Biz bu planlamadan sonra Turizm Bankası aracılığıyla mesela ilk tatil köyü projesini yaptık şeyde, Salima Tatil Köyü'nü yaptık. Turizm Bankası'nın şeyi olarak, ortağı olarak bir işletmeciyle açtık, onun projesini de biz yaptık ayrica. Turizm Bankası'ndaki proje ekibimiz bu planları yaparken aynı zamanda öncü örnek tesislerin de projelerini yapt1... (Akar 2016, s.200).

Daha önce Fransız turistler için çekici olan tatil köyleri projesi, 1980'li yıllardan itibaren Alman ve İngiliz turistlere hitap etmeye başlar; 2000'li yıllarla birlikte çok daha geniş müşteri profiline sahip olur. Halen daha devam ettirdiğimiz deniz kenarında piknik keyfiyle birlikte denize girme alışkanlığının yaşandığı 1960'lı yıllarda Foça'ya gelen Fransız turistler sörf başta olmak üzere çeşitli su sporlarını yaparlar.

Türk halkının kabul edilmediği çıplaklar kampı kısmı ise, o dönemde basının yoğun ilgisiyle karşı karşıya kalır (Hürriyet 2008). Bugün ise, İslam dünyasından olmayanların alınmadığı kadın ya da erkeklere özgü "haremlik-selamlık" uygulamalarını görmekteyiz. Türkiye'nin özellikle Akdeniz ve Ege bölgelerinde yoğunlaşan bu uygulama, özellikle belirli bir Türk tüketici kitlesi tarafından ilgi görmektedir. O dönem, koyları ayırarak çıplaklar ve diğer misafirler için ayrı alanlar yaratılırken, günümüzde bu ayrışma erkek ve kadın için ayrı mekânlar yaratılarak cinsiyet üzerinden yapılır duruma gelmiş olur.

\section{SONUÇ VE ÖNERILER}

Tarihsel gelişimi çok gerilere gitmemekle birlikte, Türkiye'de işletme bazında turizm ve seyahat sektörünün gelişim süreciyle ilgili olarak hafıza oluşumu konusunda tamamlanmış çok nadir sayıda çalışmalara rastlanmaktadır. Bunlardan birisi Ankara-İstanbul merkezli TUSAN otel-motel zincirinin gelişimi üzerinedir (Ultav ve Savaşır 2016). Bir başkası da, yiyecek-içecek, otelcilik, otobüs taşımacılı̆̆ı ve seyahat acenteciliği alanında Eskişehir'de faaliyet gösteren işletmelerin sözlü tarih yöntemliyle yazıldığ 1 tarihçesidir (Kozak 2013). Bu çalışmada ise, yine geçmişi 1960'l y yllara uzanan ve sonrasinda zincir olarak Türkiye'nin diğer şehirlerine de yayılan Club Med firmasının İzmir-Foça'da açtığı tatil köyünün tarihsel gelişimini ele alarak yerel ve ulusal düzeyde turizm sektörünün gelişimindeki rolünün yanısıra ekonomik ve sosyal yapı üzerindeki etkilerini incelemektir. 
Çalışmanın başında da vurgulandığı gibi, neoliberal politikaların hissedilmeye başlandığ 1960'lı yıllar, dünyada olduğu kadar Türkiye'de de ayrıntılı bir şekilde incelenmesi gereken bir dönemdir. Bu dönemde, ulusal ölçekte alt ve üstyapı yatırımlarının tamamlanması, turizm talebinin yaratılması, diğer ülkelerden çekim yapabilmek için tanıtım faaliyetlerine önem verilmesi gibi bir sorumlulukla hareket ederken, dünya genelinde de uluslararası ölçekte ses getirebilecek zincir işletmelerin yaratılması ve olgunlaştırılması için çaba harcanır. Yatırımı kamu tamamlarken, işletmeciliği özel sektör üstlenir. Böylelikle kamu-sektör işbirliğinin örnekleri turizm sektöründe de görülmeye başlanır. Kamu, sadece arazi vermekle kalmaz, yörenin yolu, elektriği ve suyu gibi temel gereksinimlerinin karşılanması için de katkıda bulunur.

Daha çok tarım ve balıkçılık gibi üretim biçimleriyle geçimini sağlayan yerel halk için yeni bir seçenek daha ortaya çıkar. Bir kısmı tesiste çeşitli görevler için istihdam edilirken, bir başka kısmı üretici olarak tesisin çeşitli gida gereksinimlerini karşılamakta, bir başka kısım da esnaf ya da işletmeci olarak dolaylı bir şekilde gelir elde eder. Yerel halk, elde ettiği gelir ile yeni yatırımlara girişir. Taksicilik, rehberlik, hediyelik eşya gibi yeni meslek grupları ortaya çıkar. Hem tesiste çalışanlar hem de yerel halk, yurtdışı deneyimine sahip olur. Tesiste çalışanlar arasında yabancı kadınlar ile evlenerek yurtdışına gidenler olur. Yerel halk, iletişim kurabilmek için yabancı dil öğrenmeye başlar, yeme-içme ve giyim-kuşam alışkanlığını değiştirir. Tesisin bugünkü restoran ve balık kültürünün gelişiminde de etkili olduğu düşüncesi hakimdir. Fransız kültüründen etkilenme ortaya çıkar. Tesiste konaklayan yabancı misafirlere basit Türkçe kelimeleri öğretilir, yörenin geleneği, yaşam biçimi hakkında bilgi sahibi olmaları sağlanır. Düzenlenen turlar sayesinde çevredeki tarihi ve kültürel eserler hakkında bilgi sahibi olmaları mümkün olur. Düzenlenen kültür festivali sayesinde hem yerel halkın hem de yabancı misafirlerin yerel-ulusal kültür ve sanat hakkında bilgilenmeleri sağlanır. Turizm sektöründe ilk sendikal hareketlere tanıklık yapılır. Bir bakıma Foça, tesisin, tesis de Foça'nın doğal bir parçası halini alır ve bu birliktelik yaklaşık 40 yıl sürer.
Türkiye' nin Avrupa ülkelerine ve kültürüne açılmasında önemli bir kapı rolünü üstlendiği Club Med Foça, ulusal turizm sektörünün gelişimi açısından önemine bakıldığında, aşağıdaki şekilde bir sıralamanın yapılması mümkündür:

- Yöresel ve ulusal bazda turizm sektörünün öneminin anlaşılması,

- İlk tatil köyü ve herşey dahil konseptinin ortaya çıkmış olması,

- Alaylı turizm eğitimi modelinin gelişmesine katkıda bulunmasi,

- Kamu-özel sektör işbirliğine iyi bir örnek oluşturması ve devamlılığının sağlanmasına katkıda bulunmasi,

- Merkezi ve yerel yönetimlerin turizm planlamasında yoğun bir şekilde görev almış olması,

- T.C. Emekli Sandığı'nın turizm yatırımlarının teşvik edilmesi yönündeki çabalarının devam etmesi,

- Toplumsal etkilerinin (farklı kültürde insanlarla tanışma, yabancı dil öğrenme ve öğretme, yabancilarla evlenme vb.) görülmesi,

- Ekonomik çıtılarının (yeni meslek gruplarının gelişmesi, turizm başlı başına bir sektör haline gelmesi, istihdam olanaklarının yaratılması, hizmet sektörünün diğer alanlarının gelişmesi vb.) daha çok olumlu yönde olmasıdır.

Çalışma kapsamında da değinildiği gibi, Club Med zincirinin Foça üzerinden Türkiye'ye giriş yapmasıyla birlikte, kamu ve özel sektörün turizm yatırımları, işletmeciliği ve eğitimi konusunda deneyim kazanmasına doğruda etkide bulunduğunu söylemek mümkündür. Türkiye turizm sektörüne hızlı bir giriş yaparak ulusal turizm tarihinde de bir "efsane" olarak yerini alan tesis, yerel halk açısından da bu algıyı uzun yıllar devam ettirmeyi başararak konumunu güçlendirir. Günümüzde yerel halk o yılları hala özlemle anarken; tesisin fiziksel konumu hakkındaki belirsizlik, yerel yönetimlerin ve basının gündemini de hala meşgul etmektedir. Bu çalışma kapsamında ele alınan birçok faydasına karşın tesisin kapanmasiyla birlikte, Foça ekonomisine ve toplumsal yapısına haksızlık edildiği düşüncesinin 
yerel yöneticilerde ve halk da hala hakim olduğu görülür.

Araştırmanın kısıtları arasında birkaç nokta sıralanabilir. Birincisi, sadece tesiste alt düzeyde çalışan, dönemin T.C. Turizm ve Tanıtma Bakanlığg'nda görev alan ve yine dönemin ilçe yönetiminde aktif görev alan kişiler ile görüşülmüş olup, Club Med tarafında görev alan üst düzey yabancı çalışanlar ve genel merkez çalışanları ile de görüşmelerin yapılması bir öneri olarak yer almalıdır. İkincisi, T.C. Emekli Sandığı çalışanları ile de görüşmelerin yapılması, özellikle yatırım ve kiralama aşamaları hakkında ek bilgilerin elde edilmesi için önemli olacaktır. Üçüncüsü, tesiste konaklama yapan misafirlerin dağılımının da daha geniş olması, konunun talep açısından daha iyi anlaşılması için ayrıca önemlidir. Son olarak, sadece bir başlangıç olmakla birlikte, zincirin Türkiye'deki diğer tesisleri arasında yer alan Kuşadası ve Kemer tatil köyleri için de benzer bir araştırmanın yürütülmesi mümkündür. Benzer bir araştırmanın T.C. Emekli Sandığı ya da T.C. Turizm Bankası tarafından tamamlanan diğer öncü tesislerin bölgesel ya da ulusal anlamda ortaya çıkardığı toplumsal ya da ekonomik etkileri konusunda da yapılması uygun olacaktır.

Not: Bu çalışmanın tamamlanması aşamasında gerek verdikleri bilgi gerekse ilgili kişilere yönlendirme konusunda sunmuş oldukları katkıdan dolayı Mukadder Sezgin, Prof.Dr. Nazmi Kozak, Prof.Dr. Alp Timur, Prof.Dr. Nüzhet Kahraman, Önder Kayın, Haydar Çelebi ve Nihat Dirim'e; tesisin fotoğraflarını çekme konusunda ilgi ve desteğini esirgemeyen Dr. Aslı Emine Özen De Haas ve Seyfi Gül'e teşekkürü bir borç biliriz.

\section{KAYNAKÇA}

Akar, H. (2016). Haluk Akar. İçinde N. Kozak (Editör). Türkiye Turizmi Sözlü Tarih Araştırması Görüşme Metinleri Cilt - VIII. (ss.192-206). Elektronik Basim.

Briassoulis, H. (2000). Environmental Impacts of Tourism: A Framework for Analysis and Evaluation. İçinde H. Briassoulis ve J. van der Straaten. Tourism and the Environment (ss.21-37). Hollanda: Springer.

Burkart, A.J. ve Medlik, S. (1974). Tourism: Past, Present and Future. Londra: Heinemann.

Caneday, L. ve Zeiger, J. (1991). The Social, Economic and Environmental Costs of Tourism to a Gaming Community as Perceived by its Residents, Journal of Travel Research, 30 (2): 45-49.

Club Med in Foça - A Ghost Holiday Village. Hürriyet Daily News, 6 Aralık 2008
De Wit, B. ve Meyer, R. (1998). Strategy: Process, Content, Context: An International Perspective. Londra: International Thomson Business Press.

Doğan, S. (2010). Foça Tatil Köyü için Teklif Veren Çıkmadı. Yeni Asır, 30 Ekim

Doğan, H. Z. (2004). Turizmin Sosyo-Kültürel Temelleri. Ankara: Detay Yayıncilık.

Doğan, H. Z. (1989). Forms of Adjustment: Sociocultural Impacts of Tourism, Annals of Tourism Research, 16 (2): 216-236.

Eralp, Z. (1974). Turizmin Toplumsal Değişime Sosyo-Ekonomik Etkisi. Ankara Üniversitesi Siyasal Bilgiler Fakültesi Yayin No: 374.

Fletcher, R. (2011). Sustaining Tourism, Sustaining Capitalism? The Tourism Idustry's Role in Global Capitalist Extension, Tourism Geographies, 13 (3): 443-461.

Gee, C. Y. (2008). International Hotels Development and Management. American Hotel \& Lodging Educational Institute.

Hall, C.M. ve Lew, A.A. (2009). Understanding and Managing Tourism Impacts. New York: Routledge.

Honey, M. (2008). Ecotourism and Sustainable Development: Who Owns Paradise?. 2. Bask1. Island Press, Washington D.C.

http://www.clubmed-corporate.com/?cat=188, Erişim tarihi: 1 Haziran 2016.

http://resortdergisi.com/dergi/155/\#p=184, Erişim tarihi: 10 Ocak 2016.

Inskeep, E. (1991). Tourism Planning: An Integrated and Sustainable Development Approach. New York: Van Nostrand Reinhold.

Jones, G.R. ve Hill, C.W. (2013). Theory of Strategic Management with Case. 10. Bask1, South Western Cengage Learning.

Johnson, C. ve Vanetti, M. (2005). Locational Strategies of International Hotel Chains, Annals of Tourism Research, 32 (4): 1077-1099.

Kızıltan, G. (2016). Güman Kizıltan. İçinde N. Kozak (Editör). Türkiye Turizmi Sözlü Tarih Araştırması Görüşme Metinleri Cilt-VIII. (ss.167-191). Elektronik Basım.

Kozak, M. (2013). Dünden Bugüne Eskişehir'deki 14 İşletmenin Öyküsü. Eskişehir: Tepebaşı Belediyesi.

Kozak, N., Kozak, M.A. ve Kozak, M. (2015). Genel Turizm. Ankara: Detay Yayıncılık.

Lim, H. D. ve Wentling, R. M. (1998). Modification of Transferred Training Programmes for Multinational Chain Hotels in Korea, International Journal of Training and Development, 2 (1): 17-27.

MacCannell, D. (1999). The Tourist: A New Theory of The Leisure Class. 2. Bask1. University of California Press, Berkeley.

Mathieson, A. ve Wall, G. (1992). Tourism: Economic, Physical and Social Impacts. New York: Longman.

Mill, R.C. ve Morrison, A. (1992). The Tourism System: An Introductory Text. New Jersey: Prenctice Hall International Editions.

Özaktaş, A. (2016). Adnan Özaktaş. İçinde N. Kozak (Editör). Türkiye Turizmi Sözlü Tarih Araştırması Görüşme Metinleri Cilt - VIII. (ss.303-349). Elektronik Basım. 
Özdemir, M. (1992). Turizmin Türkiye'nin Sosyo-Ekonomik Yaptsina Etkileri. Ankara: T.C. Turizm Bankası.

Sezgin, M. (2016). Mukadder Sezgin. İçinde N. Kozak (Editör). Türkiye Turizmi Sözlü Tarih Araștırması Görüşme Metinleri Cilt - VIII. (ss.303-349). Elektronik Basım.

Simpson, T. (2016). Tourist Utopias: Biopolitics and The Genealogy of The Post-World Tourist City, Current Issues in Tourism. 19 (1): 27-59.

Ultav, Z. T. ve Savaşır, G. (2016). 50. Yılının Ardından Türkiye'nin İlk Otel-Motel Zinciri: TUSAN. İzmir: Yaşar Üniversitesi Yayınları.
Vukonic, B. (2012). An Outline of The History of Tourism Theory. İçinde C.H.C. Hsu ve W.C. Gartner (Editörler). The Routledge Handbook of Tourism Research (ss. 3-27). Londra \& New York: Routledge.

Wall, G. ve Mathieson, A. (2006). Tourism: Change, Impacts and Opportunities. Essex: Pearson.

Yavuz, M. (2011). Foça'da Club Med Kapanınca Hıçkıra Hıçkıra Ağlamıştım. Yeni Asır. 18 Eylül.

Yiğit, V. (2012). Midilli'den Çıktık Yola. İstanbul: Ege Basım.

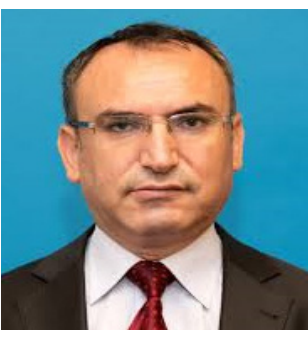

\section{Metin KOZAK}

Turizm alanında sırasıyla Çukurova Üniversitesi'nden Lisans (1991), Dokuz Eylül Üniversitesi'nden Yüksek Lisans (1993) ve Sheffield Hallam Üniversitesi'nden Doktora (2000) derecelerine sahiptir. Çeşitli araştırma burslarıyla Belçika, İngiltere, Amerika ve Hong Kong gibi ülkelerde dersler verdi, projeler yürüttü. Tüketici davranışları, destinasyon pazarlaması, sürdürülebilir turizm ve kalite yönetimi konularında çok sayıda kitap, makale ve konferans bildirisine sahiptir. Halen Dokuz Eylül Üniversitesi Reha Midilli Foça Turizm Fakültesi'nde öğretim üyesi olarak görev yapmaktadır.

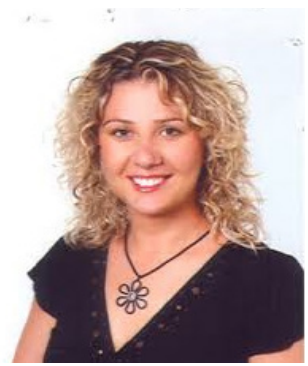

Yeşim COŞAR

Anadolu Üniversitesi İșletme Fakültesi'nden Lisans derecesi aldı (2003). Yüksek Lisans (2006) ve Doktora (2013) derecelerini Turizm İşletmeciliği alanında Dokuz Eylül Üniversitesi'nde tamamladı. Muğla Üniversitesi'nde öğretim görevlisi olarak çalıştı (2008-2012). Yavaş şehir- turizm iliş̧kisi konusunda İngiltere'de çeșitli üniversitelerde araștırmalarda bulundu. Temel çalışma alanları arasında yavaş şehir, sürdürülebilir turizm, tüketici davranışları ve turizm pazarlaması gelmektedir. Halen Dokuz Eylül Üniversitesi Seferihisar Fevziye Hepkon Uygulamalı Bilimler Yüksekokulu'nda öğretim üyesi olarak görev yapmaktadır. 